\title{
PRZESTRZENNE KONTEKSTY KONKURENCJI W SEKTORZE USLUG HOTELOWYCH
}

Zarys treści Krytyka neoklasycznego (neoliberalnego) rozumienia procesu konkurencji doprowadziła w XX wieku do wykształcenia wielu nowych kierunków badawczych w ekonomii, definiujących i interpretujących na nowo zjawiska konkurencji. Odrzucenie założeń ekonomii neoliberalnej (szczególnie w odniesieniu do równowagi rynkowej czy dostępu do informacji rynkowej) skutkowało koniecznością redefiniowania metodyki geografii ekonomicznej w zakresie badania przestrzennych aspektów konkurencji. Wreszcie, procesy zachodzące na gruncie geografii ekonomicznej wtórnie oddziaływały na rozwój nauk ekonomicznych. Celem niniejszego artykułu jest próba prześledzenia wzajemnych oddziaływań metodologicznych na linii ekonomia - geografia ekonomiczna, w zakresie badania przestrzennych kontekstów konkurencji w sektorze usług hotelowych.

Słowa kluczowe Konkurencja, ekonomia, geografia ekonomiczna, geografia turyzmu, geografia hotelarstwa.

\section{Wprowadzenie}

Celem niniejszego artykułu jest wskazanie skutków, jakie wzajemne oddziaływanie metodologiczne ekonomii i geografii ekonomicznej wywarło dla rozwoju studiów nad przestrzennymi kontekstami konkurencji przedsiębiorstw świadczących usługi hotelowe. W pierwszej części opracowania ukazano zmiany w ekonomicznej teorii konkurencji, które pojawiły się w wyniku krytyki neoklasycznego modelu konkurencji doskonałej. Zaprezentowano dorobek następujących szkół i nurtów: konkurencja monopolistyczna, szkoła austriacka z uwzględnieniem konkurencji realnej, ekonomia ewolucyjna, teoria organizacji produkcji, teoria zasobowa, teoria kompetencyjna z koncepcją współkreowania wartości, wspólnie rozpatrywana socjologia ekonomiczna, ekonomia relacyjna i teoria 
instytucjonalna oraz wreszcie syntetyczna teoria zasobowo-przewagowa. W drugiej części artykułu przedyskutowano wzajemne oddziaływanie metodologiczne ekonomii i geografii ekonomicznej w zakresie przestrzennych analiz konkurencji. Wykazano rozwój nowych nurtów geograficznych pod wpływem przemian ekonomii, jak również uwzględnienie postulatów geograficznych po odejściu od niektórych założeń neoliberalnej teorii konkurencji doskonałej. Część trzecia wskazuje na konsekwencje omówionych oddziaływań metodologicznych ekonomii i geografii ekonomicznej dla rozwoju subdyscyplin geograficznych: geografii turyzmu, a w szczególności geografii hotelarstwa. Schemat ideowy badanych oddziaływań zaprezentowano na ryc 1.

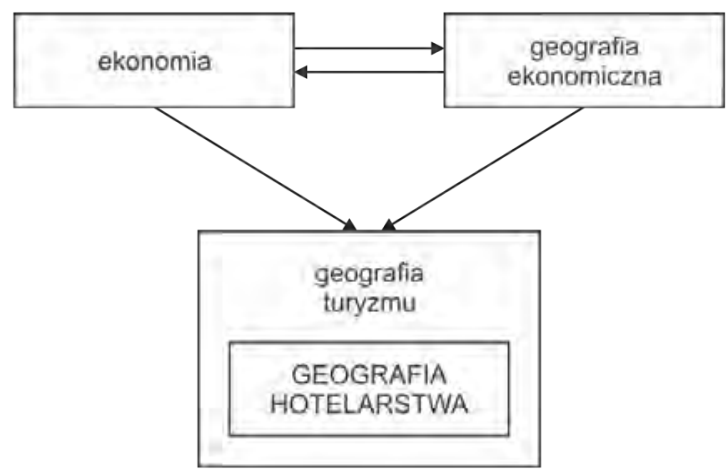

Ryc. 1. Relacje metodologiczne pomiędzy ekonomią i geografią ekonomiczną oraz ich konsekwencje dla geografii turyzmu i geografii hotelarstwa

Źródło: opracowanie własne

\section{Krytyka neoklasycznego rozumienia konkurencji w ekonomii XX i XXI wieku}

Krytyka neoliberalnej teorii konkurencji doskonałej ma zarówno aspekt metodyczny, jak i empiryczny. Pod względem metodycznym wskazuje się, że krytykowana teoria uwzględnia tylko te czynniki produkcji (ziemię, pracę i kapitał), które mają charakter policzalny, nadają się do opisania poprzez matematyczne równania (Hunt 2000). Przyjęta metodyka badań decyduje o założeniach teorii, co z perspektywy logiki procesu badawczego uznać należy za niedopuszczalne. Odrzucenie ekonomii neoklasycznej oznaczało zatem konieczność odrzucenia właściwej jej metodyki badań (Kirzner 2010). Pod względem empirycznym stwierdzono poważne niedopasowania teorii do obserwowanej rzeczywistości. W rzeczywistości mamy bowiem do czynienia z niepewnością reakcji podmiotów 
konkurencyjnych. Nie można mieć pewności co do decyzji cenowych i decyzji dotyczących wolumenu oferowanego produktu. Nie można przewidywać jaki jest horyzont czasowy decyzji podejmowanych przez konkurentów. Podobnie, nie można być pewnym co do tempa reakcji konkurentów na decyzje przedsiębiorstwa (Chamberlin 1933). M. Granovetter (1985) sugeruje, że utrzymująca się popularność teorii neoklasycznej wynika z faktu, że niezwykle atrakcyjne politycznie jest założenie o samoregulujących się strukturach rynkowych, niezależnych od tworzących je podmiotów gospodarczych zmuszonych do akceptacji cen rynkowych. Wyeliminowanie relacji społecznych z percepcji zjawisk gospodarczych sprawia, że decyzje ekonomiczne są zdecydowanie łatwiejsze do podjęcia.

Rozumienie doskonałej konkurencji w neoklasycznej ekonomii jest skrajnie różne od rozumienia biznesowego tego samego pojęcia. W ujęciu teoretycznym doskonała konkurencja jest sytuacją, w której wielość przedsiębiorstw działających na rynku jest równoczesna $\mathrm{z}$ ich akceptacją warunków rynkowych. Każdy uczestnik rynku robi to samo, co inne przedsiębiorstwa, nie ma potrzeby zdobywania przewagi konkurencyjnej nad innymi podmiotami. Zatem, doskonała konkurencja $\mathrm{w}$ ujęciu teoretycznym jest brakiem konkurencji w potocznym rozumieniu biznesowym (Kirzner 2010). E. Penrose (2011) proponuje, aby na wspomniane warunki spojrzeć w nieco odmienny sposób. Otóż środowisko działania przedsiębiorstw nie ma charakteru obiektywnego, jego charakter zależy od postrzegania przez działających w nim przedsiębiorców. Zatem, jeżeli przedsiębiorcy nie widzą możliwości podjęcia odważnych decyzji gospodarczych, tym samym rynek, a więc środowisko ich działania, przejmuje nad nimi kontrolę. Krytyka teorii neoklasycznej wynika z uwzględnienia następujących zjawisk obserwowanych w praktyce gospodarczej: 1) istnienia kosztów transakcyjnych, 2) ograniczenia dostępu do informacji, a w konsekwencji ograniczenia racjonalności decyzji gospodarczych, przy czym nieracjonalność niwelowana jest w procesie uczenia się zarówno przedsiębiorstw, jak i konsumentów, 3) niepewności i nietrwałości wykorzystywanej technologii, 4) ograniczenia mobilności zasobów wykorzystywanych w działalności gospodarczej, 5) istnienia produktów, dla których cena jest nośnikiem informacji o jakości, 6) skrajnie nieuzasadnionych, impulsywnych zachowań gospodarczych (Rumelt 1997).

$\mathrm{W}$ tabeli 1 zaprezentowano zmiany, jakie odnotowano od lat 30 . XX wieku w ekonomicznych teoriach konkurencji. Wskazano podstawowe kryteria porównania: 1) dynamikę procesu konkurencji, 2) docelowy stan, do którego prowadzi konkurencja, jak również 3) charakter popytu, podaży i produktu. Wszystkie wymienione $\mathrm{w}$ tabeli koncepcje teoretyczne zostały szczegółowo zaprezentowane w dalszej części opracowania. 
Tabela 1

Ekonomiczne teorie konkurencji

\begin{tabular}{|c|c|c|c|}
\hline $\begin{array}{c}\text { Zakres } \\
\text { porównania teorii }\end{array}$ & $\begin{array}{l}\text { Neoklasyczna } \\
\text { teoria konkurencji } \\
\text { doskonałej }\end{array}$ & $\begin{array}{c}\text { Konkurencja } \\
\text { monopolistyczna; } \\
\text { Szkoła austriacka; } \\
\text { Teoria zasobowa }\end{array}$ & $\begin{array}{c}\text { Ekonomia } \\
\text { ewolucyjna; } \\
\text { Teoria organizacji } \\
\text { przedsiębiorstw; } \\
\text { Teoria kompe- } \\
\text { tencyjna; Teoria } \\
\text { instytucjonalna; } \\
\text { Teoria zasobowo- } \\
\text {-przewagowa }\end{array}$ \\
\hline $\begin{array}{l}\text { Konkurencja ma } \\
\text { charakter: } \\
\text { dynamiczny (D), } \\
\text { statyczny (S) }\end{array}$ & $S$ & D & $\mathrm{D}$ \\
\hline $\begin{array}{l}\text { Konkurencja pro- } \\
\text { wadzi do: osią- } \\
\text { galnej równowagi } \\
\text { (R), nieosiągalnej } \\
\text { równowagi (NR), } \\
\text { nierównowagi (N) }\end{array}$ & $\mathrm{R}$ & NR & $\mathrm{N}$ \\
\hline $\begin{array}{l}\text { Popyt, podaż i pro- } \\
\text { dukt mają charak- } \\
\text { ter: homogeniczny } \\
\text { (HM), heteroge- } \\
\text { niczny (HT) }\end{array}$ & HM & HT & HT \\
\hline
\end{tabular}

Źródło: opracowanie własne na podstawie: S.D. Hunt (2000)

\subsection{Konkurencja monopolistyczna}

Teoria konkurencji monopolistycznej ukształtowała się w wyniku obserwacji równolegle działających zjawisk: konkurencji i monopolu. Jak twierdzi E. Chamberlin (1933) rzeczywista konkurencja zawiera w sobie elementy monopolistyczne, nie ma charakteru konkurencji doskonałej. Wyjaśnienie rzeczywistej konkurencji za pomocą wyłącznie teorii konkurencji doskonałej albo koncepcji monopolu nie jest możliwe. W teorii konkurencji doskonałej zakłada się, że na rynku funkcjonuje duża liczba zarówno sprzedających, jak i kupujących. Znaczenie jednego bądź nawet kilku podmiotów z perspektywy całego rynku jest praktycznie nieistotne. O konkurencji doskonałej będziemy mówić wówczas, jeżeli sprzedający, akceptując cenę rynkową, będzie w stanie sprzedać dowolną ilość wytworzonego przez siebie produktu, niezależnie od podjętych działań wspierających sprzedaż. 
Konkurencja doskonała możliwa jest wyłącznie w przypadku, gdy wszyscy sprzedający dysponują identycznym, homogenicznym, ustandaryzowanym produktem. Produkt ten dystrybuowany jest na jednorodnym rynku. Oznacza to, że zarówno sprzedający, jak i kupujący, podobnie jak będący w obrocie produkt, są również homogeniczni i ustandaryzowani, nie mogą zatem wyróżniać się niczym, co mogłoby wpływać na indywidualne preferencje poszczególnych podmiotów. W momencie gdy na rynku pojawia się jakiekolwiek zróżnicowanie produktów, sprzedawców czy konsumentów, pojawiają się tym samym zjawiska monopolistyczne, tym samym ceny równowagi niekoniecznie muszą oznaczać równowagę popytu i podaży. Najważniejszym jest dążenie do uzyskania kontroli nad zasobami pozwalającymi wyróżnić się przez producentów wśród konsumentów. Pełna kontrola nad takimi zasobami oraz ich substytutami oznacza monopol (Chamberlin 1933).

W warunkach konkurencji monopolistycznej przedmiotem obrotu są zróżnicowane produkty. Zróżnicowanie to jest podstawą do ukształtowania się preferencji konsumentów w stosunku do poszczególnych producentów. Przy założeniu konkurencji doskonałej istniał jeden rynek wielu producentów i wielu konsumentów. Natomiast w sytuacji konkurencji monopolistycznej mamy raczej do czynienia z siecią wielu powiązanych ze sobą rynków pojedynczych producentów (Chamberlin 1933). Można zatem wnioskować, że konkurencja realizowana jest również na poziomie czynników innych niż cena, przede wszystkim jakości czy promocji sprzedaży. S.D. Hunt (2011) zwraca uwagę, że teoria konkurencji monopolistycznej dała podstawy do rozwoju współczesnego marketingu, jak również wielu teorii ekonomicznych, przede wszystkim zasobowej i kompetencyjnej. Najważniejszym osiągnięciem teorii konkurencji monopolistycznej było uwzględnienie zróżnicowania produktów oraz segmentacji rynków, co wiązano z zaobserwowaną heterogenicznością popytu i postulowaną później w marketingu orientacją przedsiębiorstw na konsumentów. Opisane w pracy E. Chamberlina (1933) procesy monopolizacyjne stanowią pomost między teorią konkurencji monopolistycznej a ekonomią ewolucyjną.

W teorii konkurencji monopolistycznej nie uwzględniono natomiast faktu, że konkurencja prowadzona jest w warunkach dynamicznej rzeczywistości gospodarczej. Jest to rzeczywistość innowacji technologicznych, produktowych, marketingowych czy organizacyjnych. Zgodnie z poglądami J.A. Schumpetera (2009), proces konkurencji nie jest związany z próbą przejęcia możliwego do osiągnięcia zysku, ale z dążeniem do wyeliminowania konkurentów. Krytycy teorii konkurencji monopolistycznej zwracają również uwagę, że nie jest możliwym wskazanie jakiegokolwiek wiarygodnego modelu ekonomicznego bazującego na założeniach teorii konkurencji monopolistycznej. Implementacja omawianych modeli zawsze pociąga za sobą konieczność arbitralnego przyjęcia 
założeń upraszczających dotyczących gustów i zachowań konsumenckich, czy stosowanej i rozwijanej technologii (Krugman 1997). J.M. Clark (1955) zwraca uwagę, że teoria konkurencji monopolistycznej i teoria oligopolu nie rozwiązały podstawowych zarzutów zgłaszanych wobec teorii konkurencji doskonałej - statyczności oraz przywiązania do konieczności osiągnięcia stanu równowagi kosztowo-cenowej.

\subsection{Szkoła austriacka}

Przedstawiciele szkoły austriackiej wykazali błędy w neoklasycznym założeniu, że ekonomizowanie, czy inaczej maksymalizowanie efektu, odbywa się przy stałej strukturze celów i środków. W rzeczywistości natomiast zarówno cele działalności ekonomicznej, jak i środki, dzięki którym owe cele są osiągane, mają charakter dynamiczny (Kirzner 2010). W związku z powyższym, sensownym jest mówić nie tyle o ludzkim ekonomizowaniu (koncepcja homo oeconomicus), lecz szerzej o ludzkim działaniu (koncepcja homo agens) (von Mises 2007).

Israel Kirzner (2010) znacząco rozszerzył pojęcie konkurencji. Wskazał, że konkurowanie nie odbywa się wyłącznie na poziomie ceny, ale również rodzaju i jakości oferowanych produktów. W konsekwencji, równowaga rynkowa jest nie tylko konsensusem ceny i ilości oferowanego produktu, ale również wzorca produktu i jego ilości. Co więcej, konkurencja oznacza nie tylko produkowanie i dostarczanie produktu konsumentowi na bardziej atrakcyjnych warunkach niż inni przedsiębiorcy. Oznacza również dostarczenie konsumentowi wiedzy o produkcie. Tym samym przedsiębiorca przejmuje na siebie ciężar postaw przedsiębiorczych konsumenta. J.M. Clark (1955), który zaliczany jest do epigonów szkoły austriackiej wskazuje, że konkurencja jest zjawiskiem korzystnym dla przedsiębiorstw. Po pierwsze, konkurencja stymuluje firmy do rozwoju wykorzystywanych metod produkcji. Po drugie, dzięki konkurencji konsumenci zyskują dostęp do różnorodnych pod względem jakości czy funkcjonalności kategorii danego produktu. Po trzecie, konkurencja skutkuje wprowadzeniem na rynek nowych produktów. Charakter procesu konkurencji sprawia, że wymienione wyżej korzyści podlegają dyfuzji, dostępne stają się konsumentom, jak również pozostałym przedsiębiorcom. W wyniku dyfuzji korzyści konkurencji rozwija się cały sektor, zyskują zatem wszyscy pojedynczy konkurenci. Procesy dyfuzyjne stymulowane są poszukiwaniem przez konsumentów informacji o produktach konkurencyjnych, jak również stopniem wolności gospodarczej. Dynamiczna teoria konkurencji realnej J.M. Clarka (1955) określa zasady, na jakich następują zwrotne reakcje przedsiębiorstwa i jego konkurentów. Reakcje te obrazuje ryc. 2 . 


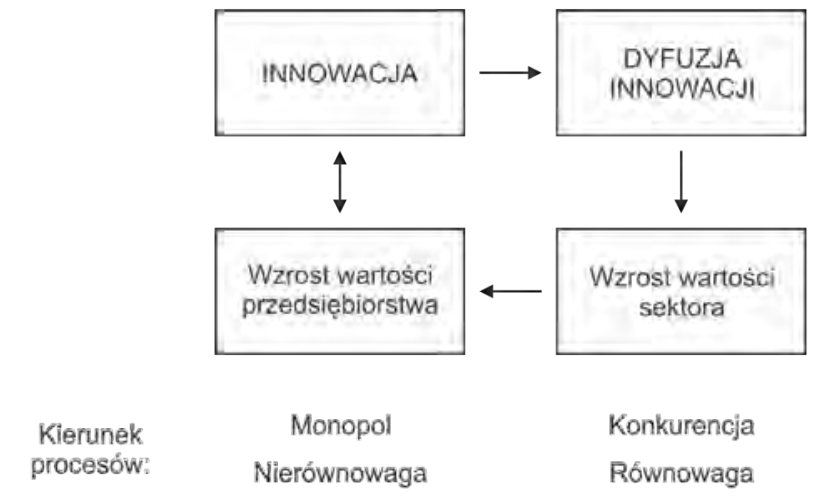

Ryc. 2. Wzrost wartości przedsiębiorstw w wyniku rozwoju innowacyjności i konkurencyjności

Źródło: opracowanie własne na podstawie: J.M. Clark (1955: 455)

\subsection{Ekonomia ewolucyjna}

Jedną z ważniejszych teorii ekonomicznych XX wieku, będącą podstawą innych szkół ekonomicznych, jest ekonomia ewolucyjna, której podstawy opracował J.A. Schumpeter (2009). Zgodnie z jego poglądami, gospodarka rynkowa ma zawsze charakter dynamiczny, co wynika z następujących przesłanek. Po pierwsze, dynamiczny charakter gospodarowania związany jest z przemianami zachodzącymi w środowiskach społecznym i przyrodniczym, w których zakorzenione są wszelkie działania gospodarcze. Po drugie, mechanizm rynkowy sam zmienia warunki swojego istnienia, głównie poprzez zmiany wielkości dostępnego kapitału. Wreszcie po trzecie, o dynamice kapitalizmu decydują wszelkiego rodzaju innowacje (nowe produkty, rynki, formy organizacji działalności gospodarczej), czyli tzw. „twórcze burzenie” (Schumpeter 2009). Innowacje podzielić można ze względu na dwa kryteria: skalę oryginalności oraz obszar działalności przedsiębiorstwa, którego dotyczą. Ze względu na oryginalność mówić można o innowacjach mało znaczących, posiadających znaczenie dla firmy, oraz posiadających znaczenie dla całej gospodarki, czyli tzw. innowacjach radykalnych. W ramach drugiego kryterium wyróżnić trzeba innowacje produktowe, technologiczne, marketingowe, organizacyjne oraz dystrybucyjne (Szutowski 2016).

W ekonomii ewolucyjnej przyjmuje się następujące założenia badawcze: 1) podmioty podejmujące decyzje gospodarcze nie dysponują wystarczającą informacją, nie mogą zatem zachowywać się w sposób racjonalny, optymalny, 2) decyzje gospodarcze uwarunkowane są obowiązującymi zasadami i normami, kształtowane są przez zwyczaje i instytucje, 3) podmioty uczestniczące w systemie gospodarczym posiadają zdolność wytwarzania innowacji i imitowania siebie 
nawzajem, 4) procesy innowacji i imitacji konstytuują ewolucję, która ma charakter nierównowagowy, nieregularny, nieprzewidywalny co do skutku (sukces lub niepowodzenie, zysk lub strata), niedeterministyczny, nieteleologiczny oraz nieodwracalny, 5) ekonomia ewolucyjna jest teorią endogeniczną, wyjaśnia zatem procesy gospodarcze z perspektywy dynamiki wnętrza przedsiębiorstw (Glapiński 2013).

Jak twierdzi J.A. Schumpeter (2009), wzrost gospodarczy należy utożsamiać z procesami monopolizacji. Naturalną konsekwencją rozwoju przedsiębiorstw jest ich stopniowe przekształcanie w korporacje. Co istotne, właściwość ta stała się inspiracją do opracowania przez E. Penrose (2011) założeń teorii zasobowej. Rozwój korporacji eliminuje z rynku małe i średnie przedsiębiorstwa. Jednakże, proces ten jest znacząco ograniczony przez działalność administracji państwowej i samorządowej. Z perspektywy politycznej, likwidacja małych i średnich przedsiębiorstw uderza wszakże w znacznie większą część elektoratu niż stanowioną przez kierownictwo ponadnarodowych przedsiębiorstw (Schumpeter 2009).

A. Glapiński (2013) podaje następujące ograniczenia przyjęcia teorii ewolucyjnej w ekonomii. Ekonomia ewolucyjna ma charakter skrajnie empiryczny, co skutkuje trudnością wywiedzenia uogólnień, szczególnie w formie modeli ekonometrycznych. Rozwiązaniem tego problemu jest wykorzystanie teorii gier, dzięki czemu ekonomia ewolucyjna zyskała dostęp do nowej metody badawczej - eksperymentu. Przywiązanie do empiryzmu skutkuje również tym, że teorię ekonomiczną trudno oddzielić od historii gospodarczej. Kolejnym ograniczeniem ekonomii ewolucyjnej jest trudność formułowania hipotez, których weryfikacja możliwa jest poprzez falsyfikację. Wreszcie, współczesna ekonomia ewolucyjna ma niezwykle eklektyczny charakter, wykorzystuje dorobek wielu różnorodnych dyscyplin (np. socjologia, antropologia społeczna, historia gospodarcza, ekonomia instytucjonalna, ekonomia behawioralna, ekonomia eksperymentalna, psychologia ewolucyjna, psychologia społeczna). Wspomniany eklektyzm komplikuje metodykę badań realizowanych na gruncie ekonomii ewolucyjnej.

\subsection{Teoria organizacji}

Teoria organizacji jest raczej dziedziną aplikacyjnej wiedzy biznesowej dotyczącej zarządzania relacjami konkurencyjnymi niż teorią ekonomiczną. M.E. Porter (2006), najbardziej rozpoznawalny przedstawiciel omawianej szkoły, wyróżnia następujące czynniki determinujące strategie konkurencji formułowane przez przedsiębiorstwa: 1) silne i słabe strony firmy, 2) okazje i zagrożenia występujące w otoczeniu przedsiębiorstwa, 3) indywidualne cechy osób odpowiedzialnych za wybór i wdrożenie strategii konkurencji w firmie, 4) oczekiwania ujawniane przez interesariuszy przedsiębiorstwa. Dynamika procesów konkurencyjnych jest zależna od sił napędowych konkurencji w sektorze. Warto podkreślić, że konkurentami przedsiębiorstwa nie będą wyłącznie firmy wytwarzające podobne produkty, ale 
również potencjalni konkurenci bądź firmy, które będą w stanie wytworzyć produkt substytucyjny. W relacjach konkurencyjnych przedsiębiorstwo może konkurować również ze swoimi dostawcami, jak i nabywcami (Porter 2006) - ryc. 3.

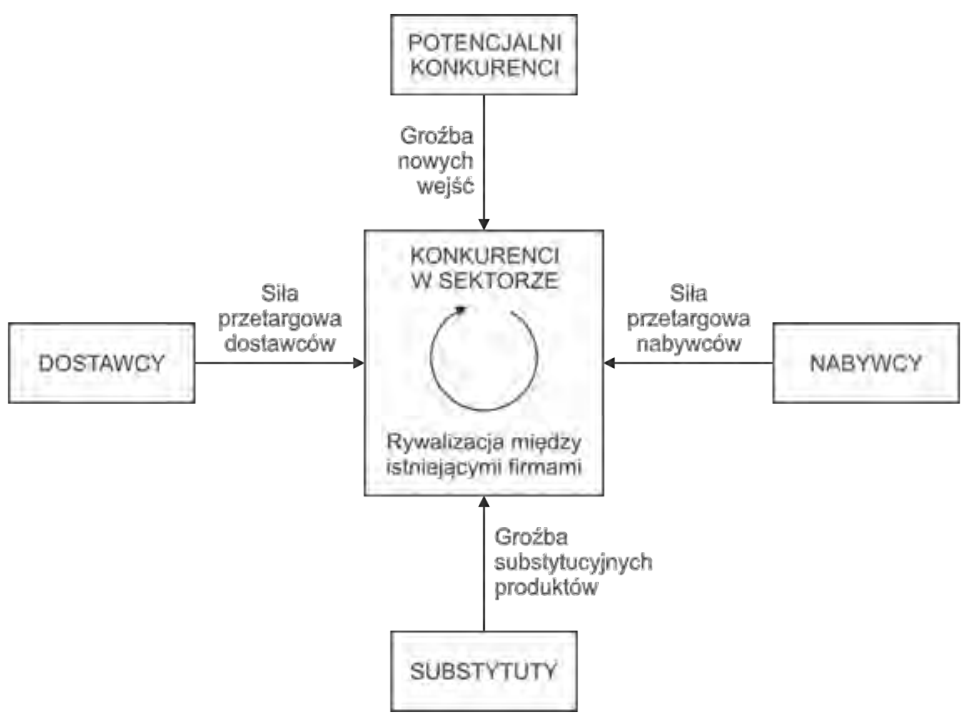

Ryc. 3. Siły napędowe konkurencji w sektorze

Źródło: opracowanie własne na podstawie: M.E. Porter (2006: 24)

Co ważne, M.E. Porter (2006) odrzuca założenie o pełnej wiedzy przedsiębiorców podejmujących decyzje gospodarcze. Podkreśla, że brak wiedzy lub błędne rozpoznanie rzeczywistych warunków rynkowych może być powodem podjęcia błędnej decyzji przez firmę, a to w konsekwencji może przyczynić się do wyboru innej strategii przez przedsiębiorstwa konkurencyjne. M.E. Porter i V.E. Millar (2001) już w połowie lat 80 . XX w. zauważyli, że dysponowanie wiedzą pozwalającą wdrażać do działalności innowacyjne technologie informacyjne i komunikacyjne staje się kluczowym zasobem pozwalającym przedsiębiorstwom osiągać przewagę konkurencyjną. Obserwowana rewolucja informacyjna i komunikacyjna oddziałuje na procesy konkurencyjne zmieniając struktury sektorów: zwiększa siłę nabywców, podwyższa bariery wejścia, zwiększa groźbę pojawienia się produktów substytucyjnych i zmniejsza siłę dostawców. Warto jednak pamiętać, że autorzy zdefiniowali wskazane oddziaływania głównie w odniesieniu do działalności produkcyjnej, a nie usługowej. Nie ulega jednak wątpliwości, że nowoczesne technologie informacyjne i komunikacyjne służą przede wszystkim zacieśnieniu relacji pomiędzy firmą a jej dostawcami i nabywcami, pozwalają często na współdzielenie zasobów. Należy dodatkowo podkreślić, że dyskutowana rewolucja skutkuje nie tylko zmianami w istniejących sektorach, ale jednocześnie powoduje powstanie całkiem nowych rodzajów działalności gospodarczej (Porter i Millar 2001). 


\subsection{Teoria zasobowa}

E. Penrose (2011), uznawana za twórczynię teorii zasobowej, zanegowała uniwersalizm teorii ekonomicznych, wskazała, że obowiązują one wyłącznie w określonych warunkach. Definiując swoją zasobową teorię rozwoju firmy opierała się na analizie zjawisk gospodarczych zachodzących od końca XIX wieku. Podkreślała, że sprawdza się ona wyłącznie w odniesieniu do zarejestrowanych prywatnych przedsiębiorstw działających w warunkach, w których międzynarodowa korporacja jest szczytową formą rozwoju firm. Głównymi problemami badawczymi teorii zasobowej są przyczyny istnienia oraz rozmiary i cele działalności przedsiębiorstw (Conner 1991).

Należy podkreślić, że fizycznie rozumiane zasoby nie powinny być traktowane jako czynniki produkcji. Znaczenie mają usługi, które przedsiębiorstwo otrzymuje dzięki wykorzystaniu zasobów. Zatem, zasoby można uznać za nośnik usług wykorzystywanych przez firmę w jej działalności. Nie jest zatem istotne co jest wykorzystywane w działalności przedsiębiorstwa, ale jak jest wykorzystywane (Penrose 2011). J. Barney (1991) dzieli zasoby przedsiębiorstwa na trzy kategorie: kapitał fizyczny, ludzki i organizacyjny. Co ciekawe, lokalizację geograficzną traktuje, obok majątku trwałego oraz wartości niematerialnych i prawnych, jako składnik kapitału fizycznego. Nie uwzględnia zatem kulturowych i społecznych aspektów lokalizacji.

E. Penrose (2011) wprowadziła pojęcie kluczowych zasobów przedsiębiorstwa, a więc zasobów decydujących o osiąganiu przez firmę relatywnie trwałej przewagi konkurencyjnej. J. Barney (1991) podkreśla, że dany zasób przedsiębiorstwa będzie mógł być uznany za kluczowy jeżeli spełni cztery warunki: 1) będzie posiadał wartość z perspektywy neutralizacji zagrożeń lub wykorzystania szans pojawiających się w środowisku firmy, 2) będzie rzadki, co oznacza utrudniony dostęp do zasobu dla obecnych lub potencjalnych konkurentów, 3) będzie go trudno podrobić lub 4) zastąpić innym zasobem o podobnej wartości, ale powszechnie dostępnym lub łatwo imitowalnym. Według B. Czerniachowicz (2012) kluczowe zasoby, którymi dysponuje przedsiębiorstwo to składniki kapitału ludzkiego. Są to przede wszystkim wiedza i kompetencje pracowników, ale również zdolności przywódcze kadry menedżerskiej. R.P. Rumelt (1997) wskazuje, że dla rozwoju przedsiębiorstwa kluczowe znaczenie mają przede wszystkim decyzje strategiczne podejmowane przez kierownictwo, a dotyczące relacji firmy z jej konkurentami. Kluczowe zasoby przedsiębiorstwa mają charakter unikalny, nie są w prosty sposób dostępne innym firmom, nie da się ich łatwo podrobić ani zastąpić. Powyższe wynika z faktu, że kluczowych zasobów firma nie może kupić (zapasy), a jedynie samodzielnie stworzyć, imitować lub zastąpić (zasoby niematerialne), najczęściej w długotrwałym i kosztochłonnym procesie (Dierickx i Cool 1989). 
K.R. Conner (1991) przedstawia podobieństwa i różnice między teorią zasobową a ekonomią ewolucyjną. Tym co łączy oba spojrzenia jest wskazanie dynamiki relacji konkurencyjnych jako czynnika stymulującego przychody przedsiębiorstw. Postawa przedsiębiorcza jest zatem kluczową siłą rozwoju gospodarczego. Obie teorie wskazują na trwałość ryzyka pojawienia się nowych konkurentów. Jednakże w teorii zasobowej sugeruje się, że innowacje mogą mieć charakter egzogeniczny, powstać poza przedsiębiorstwem, mimo że to firma będzie ich beneficjentem. Przykładem takich zmian może być rewolucyjna zmiana gustów klientów bądź dostarczenie nowej technologii przez zewnętrzne jednostki badawczo-rozwojowe. W teorii zasobowej podkreśla się również, że osiąganie satysfakcjonujących przychodów może być właściwością przedsiębiorstw mniej innowacyjnych.

\subsection{Teoria kompetencyjna}

P. Bartkowiak (2014) zaznacza, że we wszystkich teoriach ekonomicznych, które pojawiły się przed koncepcją współkreowania wartości opracowaną na gruncie teorii kompetencyjnej zakładano, że to przedsiębiorca samodzielnie decyduje o wartości produktu. Przyjmowano zatem, że produkt a priori posiada wartość dla konsumenta. Jak wskazują C.K. Prahalad i G. Hamel (1990), celem firm była dotąd koncentracja na poszczególnych produktach, których produkcja miała stać się maksymalnie efektywna. Współcześnie, rzeczywistość gospodarcza zmienia się niezwykle dynamicznie. W związku z powyższym produkt, w którego wytwarzaniu firma się wyspecjalizowała, może w krótkiej perspektywie okazać się całkowicie nieprzydatny dla konsumentów. Zatem, przedsiębiorstwo powinno specjalizować się nie tyle w dostarczaniu konkretnego produktu na rynek, ile na nieustannym poszukiwaniu nowych rynków. Do takich działań niezbędne są zupełnie inne zasoby, głównie kompetencyjne, dotyczące pracowników, a przede wszystkim menedżerów.

Mówiąc o przykładowych kluczowych kompetencjach warto wskazać na następujące: umiejętność harmonizacji zmieniających się procesów technologicznych i struktury organizacyjnej firmy, komunikacja kierownictwa z interesariuszami przedsiębiorstwa, zaangażowanie interesariuszy przedsiębiorstwa czy zdolność interesariuszy do konsensusu wobec wyzwań rozwoju firmy. Co więcej, samo spojrzenie na firmę musi ulec zmianie, szczególnie w długim okresie. Firma nie będzie już postrzegana jako zbiór przedsięwzięć (tzw. strategicznych jednostek biznesu), stanie się natomiast kolekcją kluczowych kompetencji. C.K. Prahalad i G. Hamel (1990) uzupełnili definicję zasobów kluczowych przedsiębiorstwa, pierwotnie określoną na gruncie teorii zasobowej. Wskazali, że kompetencje decydując o przewadze konkurencyjnej powinny mieć istotny wkład w tworzenie wartości postrzeganej przez konsumentów końcowych produktów przedsiębiorstwa. 
Ze względu na fakt, że współcześni konsumenci nawiązują silne relacje między sobą, lepiej mówić o ,sieciowym współkreowaniu wartości” (Bartkowiak 2014). Warto podkreślić, że do sieci łączących konsumentów przedsiębiorstwa dołączyć mogą inni interesariusze firmy. Co ważne, współcześni konsumenci funkcjonują w wysoce złożonych strukturach: ujawniają złożone, wysoce zindywidualizowane potrzeby, na które odpowiedzią są podobnie kompleksowe (składające się zazwyczaj z wysokiej jakości usług) i zindywidualizowane produkty. Na takim specyficznym rynku coraz częściej ujawniają się charakterystyczne postawy konsumentów: początkowo ponadprzeciętne zaangażowanie w poszukiwanie informacji o produktach, a docelowo pragnienie współtworzenia produktu. Powyższe zjawisko określane przez A. Tofflera (1997) jako „prosumpcja” jest szczególnie często obserwowane na rynkach turystycznych (Niezgoda 2013; Markiewicz i Niezgoda 2015).

Współcześnie jednym z istotnych wymiarów konkurencji jest współpraca między konkurującymi przedsiębiorstwami, tzw. „współpraca konkurencyjna” (Hamel i in. 1989). Współpraca ta realizowana jest w różnorakich formułach, np.: joint-venture, umów outsourcingowych czy franczyzowych, umów dotyczących realizacji wspólnych projektów badawczych. Należy podkreślić, że każde z przedsiębiorstw podejmujących współpracę zachowuje odrębność w formułowaniu swoich celów, które wytyczają granice partnerstwa przedsiębiorstw. Podstawowym celem współpracy konkurencyjnej jest najczęściej możliwość skorzystania z zasobów pozostających w dyspozycji konkurenta, np. wiedzy, technologii, doświadczenia w funkcjonowaniu na określonym rynku. Warto podkreślić, że współpraca konkurencyjna jest znakomitym przykładem niskokosztowej strategii konkurencyjnej (Hamel i in. 1989).

Teoria kompetencyjna wywarła szczególny wpływ na rozwój współczesnego marketingu. Już na początku lat 80 . XX wieku w teorii marketingu pojawiły się koncepcje odmienne od popularnej idei „4P” zdefiniowanej na gruncie teorii organizacji (McCarthy 1968). Dekadę później dobitnie sugerowano konieczność poszukiwania odmiennego paradygmatu marketingu. Przyczyną był fakt, że popularna koncepcja „4P” została opracowana w oparciu o analizy rynków, na których dominowała sprzedaż dóbr. Współcześnie zaś, największe znaczenie mają rynki usługowe (Vargo i Lusch 2004).

\subsection{Socjologia ekonomiczna, ekonomia relacyjna i teoria instytucjonalna}

Z perspektywy socjologicznej, dorobek ekonomiczny można podzielić na ten, w którym znaczenie czynników społecznych w analizie zjawisk gospodarczych zostało bądź przeszacowane, bądź niedoszacowane. Niedoszacowanie działań i relacji ludzkich w koncepcjach ekonomicznych jest typowe dla tradycji neoklasycznej. Dyskusji poddano przeciwne teorie, jak utylitaryzm czy częściowo 
ewolucjonizm, w których wskazywano na zbyt wielką, zdaniem krytyków, wrażliwość uczestników życia gospodarczego na opinie innych osób, bezrefleksyjne poddanie się dyktatowi zasad i norm oraz tworzących i sankcjonujących je ludzi i instytucji (Granovetter 1985).

Za prekursora socjologii ekonomicznej uznać można M. Webera (2015). Wprowadził on pojęcie „ducha kapitalizmu”. Wskazał, że rozumienie tego pojęcia $\mathrm{w}$ etyce protestanckiej uległo poważnym przeobrażeniom. Nie mniej jednak, to protestantyzm ukonstytuowal kwestie związane $\mathrm{z}$ gospodarowaniem $\mathrm{w}$ problematyce badawczej etyki. M. Weber (2015) twierdzi, że to właśnie wspomniany duch kapitalizmu, a nie kapitał był źródłem rozwoju gospodarczego. Widoczny w postawach społecznych żywotny duch kapitalizmu jest w stanie stymulować powstanie odpowiednich zasobów, również kapitałowych, niezbędnych do rozwoju przedsiębiorstw, a w konsekwencji rozwoju całego systemu gospodarczego. R. Swedberg (2003) omawiając dorobek Webera zwraca uwagę, że racjonalizm zachodnich społeczeństw był (i często ciągle jest) wskazywany powszechnie jako wyznacznik rozwoju krajów o gorszej sytuacji gospodarczej. Kraje rozwijające się musiały akceptować zachodnie wartości jako cel procesu, którego efektem miała być pozycja kraju nowoczesnego.

Współczesna socjologia ekonomiczna dyskutuje nie tylko kulturowe uwarunkowania procesów gospodarczych. Wskazuje również inne zjawiska determinujące zachowania ekonomiczne: zakorzenienie współczesnych producentów i konsumentów w strukturach sieciowych czy uwarunkowania instytucjonalne (Swedberg 2003), jak również przenikanie się relacyjnych struktur społecznych i gospodarczych (Granovetter 1985), które B. Uzzi (1996) nazywa „zakorzenieniem" działań gospodarczych w strukturach społecznych. Socjologia ekonomiczna nie jest co prawda w stanie zmierzyć wpływu motywacji osobistych i uwarunkowań instytucjonalnych na zyskowność przedsiębiorstw, aczkolwiek pomaga to oddziaływanie zrozumieć, umożliwia identyfikację mechanizmu tego oddziaływania. Do podstawowej terminologii socjologii ekonomicznej należy zaliczyć takie pojęcia, jak „zaufanie” w kontrze do „okazji rynkowych” (Granovetter 1985; Uzzi 1996), „,norma” zestawiona z ,interesem” (Swedberg 2003).

\subsection{Teoria zasobowo-przewagowa}

Zasobowo-przewagowa teoria konkurencji została opracowana przez S.D. Hunta (2000) jako synteza dotychczasowego dorobku ekonomicznego w zakresie konkurencji. Koncepcja ta umożliwia wyjaśnienie efektywności przedsiębiorstw w gospodarce rynkowej dzięki dwóm założeniom. Po pierwsze, przedsiębiorstwa są jednostkami działającymi w określonym kontekście przestrzennym i czasowym. Po drugie, firmy i wykorzystywane przez nie zasoby są jednostkami podlegającymi selekcyjnym procesom konstytuowanym przez konkurowanie o przewage 
komparatywną. Teoria zasobowo-przewagowa traktuje przedsiębiorstwa jako jednostki posiadające określony kontekst historyczny i geograficzny. W teorii zasobowo-przewagowej zarówno przedsiębiorstwa, jak i zasoby, z których korzystają w swojej działalności, podlegają ewolucyjnej selekcji, która konstytuowana jest przez proces konkurencji na rzecz osiągnięcia przewagi komparatywnej (Hunt 2000).

Konkurencja w teorii zasobowo-przewagowej jest rozumiana jako proces dążący do nierównowagi rynkowej, obejmujący rywalizację przedsiębiorstw o uzyskanie komparatywnej przewagi w dostępie do zasobów, których wykorzystanie umożliwia osiągnięcie korzyści wynikających z konkurencyjnej przewagi w określonych segmentach rynku, a w konsekwencji - osiągnięcie relatywnie lepszych wskaźników finansowych działalności. Procesy konkurencyjne zależą od następujących czynników zewnętrznych: 1) zasobów ekonomicznych i społecznych, z których firma korzysta w swojej działalności, 2) instytucji społecznych tworzących struktury działalności firmy, 3) działań podejmowanych przez konkurentów i dostawców, 4) zachowań konsumentów i 5) polityki gospodarczej państwa i samorządu. Konkurencja uwarunkowana jest również czynnikami wewnętrznymi: 1) innowacyjnością i 2) zdolnością uczenia się przedsiębiorstwa (Hunt 2000). Dynamika procesów konkurencyjnych jest uwarunkowana m.in. brakiem zdolności przedsiębiorstw do wytwarzania produktów w pełni substytucyjnych w stosunku do produktów oferowanych przez konkurencję. Brak pełnej substytucji wynika z unikalnych, zmiennych w czasie i przestrzeni warunków podejmowania każdej decyzji przez przedsiębiorstwa: niepowtarzalnych korzyści lokalizacji i dynamicznego zapotrzebowania na zróżnicowane zasoby (Hunt 2000).

Teoria zasobowo-przewagowa, podobnie jak ekonomia ewolucyjna, traktuje konkurencję jako proces nierównowagowy, w przeciwieństwie do teorii zasobowej czy szkoły austriackiej, które wskazują, że celem konkurencji jest osiągnięcie równowagi rynkowej. W teorii zasobowo-przewagowej konkurencja jest procesem rywalizacji przedsiębiorstw, ma charakter selekcyjny. Wszystkie przedsiębiorstwa dążą do uzyskania przewagi konkurencyjnej. Zatem, ewentualny stan równowagi, w którym każda firma na rynku osiąga satysfakcjonujące wyniki finansowe, ma charakter skrajnie nietrwały. Sytuacja ta motywuje przedsiębiorstwa do rozwijania wiedzy o tym, jak uzyskiwać i bronić osiągniętą przewagę konkurencyjną. Warto podkreślić, że wiedza taka uznawana jest współcześnie za jeden z istotniejszych czynników produkcji (Hunt 2000).

Zasoby wykorzystywane $\mathrm{w}$ działalności przedsiębiorstw obejmują w teorii zasobowo-przewagowej następujące składniki: 1) finansowe, nazywane też często kapitałem finansowym, 2) materiałowe (np. maszyny i urządzenia), 3) prawne (np. znaki towarowe, licencje, patenty), 4) ludzkie, inaczej kompetencyjne, nazywane również kapitałem ludzkim (np. wiedza i umiejętności poszczególnych pracowników), 5) organizacyjne, zwane także kapitałem organizacyjnym (kultura korporacyjna, na którą składają się procedury i zwyczaje obowiązujące w przedsiębiorstwie), 6) informacyjne, nazywane kapitałem kognitywnym 
(będąca często wynikiem własnych prac badawczo-rozwojowych, pozostająca w dyspozycji firmy wiedza o rynku, konkurentach, dostawcach, technologii) oraz 7) relacyjne, określane często jako kapitał społeczny (mowa o stosunkach łączących przedsiębiorstwo z podmiotami otoczenia, a więc dostawcami i konkurentami - przykładem takich relacji są alianse strategiczne z klientami, organizacjami, instytucjami państwowymi i samorządowymi). Co ważne, nie jest istotnym posiadanie, ale możliwość dysponowania wymienionymi zasobami. Jak widać, zasoby są niezwykle zróżnicowane. Bardzo istotnym jest również fakt, że nie wszystkie zasoby podlegają procesowi wymiany, nie jest możliwym ich proste przenoszenie pomiędzy firmami (Hunt 2000).

W tabeli 2 wskazano najistotniejsze różnice pomiędzy neoklasyczną teorią konkurencji doskonałej a teorią zasobowo-przewagową. Należy podkreślić skalę różnic pomiędzy porównywanymi teoriami. Trzeba jednocześnie przypomnieć, że teoria zasobowo-przewagowa powstała jako synteza dorobku ekonomicznego krytycznie odnoszącego się do teorii neoliberalnej, a powstałego od lat 30. do końca $\mathrm{XX}$ wieku. Tym samym warto zaznaczyć ogromny postęp, jaki uczyniła ekonomia w rozumieniu procesów konkurencyjnych w ciągu ostatnich kilkudziesięciu lat.

Tabela 2

Neoklasyczna teoria konkurencji doskonałej a teoria zasobowo-przewagowa

\begin{tabular}{lll}
\hline \multicolumn{1}{c}{ Zakres porównania teorii } & \multicolumn{1}{c}{$\begin{array}{c}\text { Neoklasyczna teoria } \\
\text { konkurencji doskonałej }\end{array}$} & Teoria zasobowo-przewagowa \\
\hline Popyt & $\begin{array}{l}\text { Homogeniczny i statyczny } \\
\text { W ramach danej gałęzi } \\
\text { gospodarki }\end{array}$ & Heterogeniczny i dynamiczny \\
\hline $\begin{array}{l}\text { Wiedza konsumenta/przedsię- } \\
\text { biorstwa pozwalająca podej- } \\
\text { mować decyzje gospodarcze }\end{array}$ & Pełna i darmowa & $\begin{array}{l}\text { Niepełna, jej zdobycie } \\
\text { wymaga poniesienia nakładów }\end{array}$ \\
\hline $\begin{array}{l}\text { Motywacja ludzka do } \\
\text { podejmowania aktywności } \\
\text { gospodarczych }\end{array}$ & $\begin{array}{l}\text { Egoistyczna maksymalizacja } \\
\text { własnych korzyści } \\
\text { (homo oeconomicus) }\end{array}$ & $\begin{array}{l}\text { Poszukiwanie własnych } \\
\text { korzyści ograniczone } \\
\text { własnym kodeksem etycznym } \\
\text { (homo agens) }\end{array}$ \\
\hline Cel przedsiębiorstwa & Maksymalizacja zysku & $\begin{array}{l}\text { Poprawa wskaźników } \\
\text { działalności }\end{array}$ \\
\hline Czynniki produkcji & Ziemia, praca i kapitał & $\begin{array}{l}\text { Finansowe, materiałowe, } \\
\text { prawne, ludzkie, organizacyj- } \\
\text { ne, informacyjne i relacyjne }\end{array}$ \\
\hline Zadanie menedżerów & $\begin{array}{l}\text { Określić i urzeczywistnić } \\
\text { pożądany wolumen produkcji }\end{array}$ & $\begin{array}{l}\text { Rozpoznać, zrozumieć, } \\
\text { kreować, wybrać, wdrożyć } \\
\text { i modyfikować strategie }\end{array}$ \\
\hline Istota procesu konkurencji & $\begin{array}{l}\text { Zmierzający do równowagi } \\
\text { rynkowej; Innowacje mają } \\
\text { charakter zewnętrzny } \\
\text { względem przedsiębiorstwa }\end{array}$ & $\begin{array}{l}\text { Zmierzający do nierównowagi } \\
\text { rynkowej; Innowacje } \\
\text { zachodzą wewnątrz } \\
\text { przedsiębiorstwa }\end{array}$ \\
\hline Źrodlo: S.D. Hunt (2000: 106) & \\
\hline & &
\end{tabular}

Źródło: S.D. Hunt (2000: 106) 


\section{Geograficzne badania konkurencji jako konsekwencja nowych nurtów ekonomicznych}

J. Howells i J. Bessant (2012) zwracają uwagę, że geografia ekonomiczna jest przykładem dyscypliny naukowej niezwykle otwartej na nowe teorie badawcze powstałe na gruncie innych nauk, a w szczególności ekonomii. Jako przykład podają rozwój nurtu behawioralnego w geografii ekonomicznej od lat 60 . XX w. czy uwzględnienie teorii organizacji w geografii przemysłu od lat 80 . XX w. P. Krugman (1997) zwraca natomiast uwagę na problem związany z trudnościami implementacji modeli geograficznych na gruncie teorii ekonomicznych. Wskazuje, że teorie gospodarcze powstałe na gruncie geografii ekonomicznej wyprzedzały często ekonomiczną krytykę neoklasycznej teorii konkurencji doskonałej. Przykładem jest choćby teoria ośrodków centralnych, której założenia wskazują na dynamiczny charakter opisywanej rzeczywistości, są więc całkowicie sprzeczne z założeniami krytykowanej, neoliberalnej teorii. Mamy więc do czynienia z sytuacją, w której gospodarcze teorie geograficzne zostały dostrzeżone w ekonomii dopiero w momencie, gdy sami ekonomiści zdecydowali się na odejście od obowiązujących założeń teorii neoklasycznej.

J. Howells i J. Bessant (2012) wyróżniają pięć podstawowych problemów badawczych, których rozwiązaniem powinna zająć się współcześnie geografia ekonomiczna. Pierwszym zagadnieniem jest optymalizacja podejmowanych decyzji lokalizacyjnych. Chodzi nie tylko o wskazywanie samej lokalizacji przedsiębiorstwa, ale również o rozstrzygnięcie skali działań i funkcji realizowanych przez firmę w danej lokalizacji. Drugim problemem ważnym dla geografów ekonomicznych powinna być optymalizacja struktur przestrzennych działalności przedsiębiorstw. Ważne są zatem badania nad takimi zjawiskami, jak: 1) koncentracja działalności gospodarczej, w tym tworzenie klastrów gospodarczych, 2) efekty rozprzestrzeniania się (z ang. spillovers) oraz 3) tworzenie sieci łączących nie tylko przedsiębiorstwa, ale również ich interesariuszy. Trzeci problem badawczy wynika $z$ odrzucenia neoklasycznego założenia o pełnej racjonalności decyzji podejmowanych przez przedsiębiorców i uznania istnienia tzw. kosztów transakcyjnych. $Z$ tej perspektywy kluczowe stają się badania relacji społecznych pomiędzy wszystkimi interesariuszami przedsiębiorstw, które szczególnie w przypadku inwestycji zagranicznych będą miały istotny kontekst przestrzenny. Czwarty problem badawczy dotyczy zależności pomiędzy rozwojem przestrzeni a rozwojem przedsiębiorczości. Wskazać należy bowiem, że dynamika rozwoju obszaru jest pochodną rozwoju działających $\mathrm{w}$ nim przedsiębiorstw. Zależność ma również charakter odwrotny. O tym jak będą rozwijać się firmy, decydować będą uwarunkowania przestrzeni lokalnej, regionalnej, krajowej czy globalnej. Ostatni, piąty problem badawczy dotyczy innowacji rozumianej w ekonomii ewolucyjnej jako kluczowy element określający dynamikę firm i całych systemów gospodarczych. 
Dla geografów ekonomicznych kluczowe będzie określenie wpływu innowacji na zmiany preferencji lokalizacyjnych przedsiębiorstw (Howells i Bessant 2012).

P. Maskell (2001) zauważa, że zdecydowana większość geografów ekonomicznych odrzuca neoliberalne założenie o pełnej racjonalności działań podejmowanych przed gospodarujące podmioty. Jednocześnie nadal pozostaje pod przemożnym wpływem neoklasycznego dorobku dotyczącego przestrzennych kontekstów gospodarczych (m.in. Lösch 1961; Morrill 1974). Oparte o założenia ekonomii neoklasycznej geograficzne modele konkurencji wskazują, że wszystkie struktury społeczne maksymalizują przestrzenną efektywność swoich działań. Dążą do przemieszczeń o największym natężeniu i jednocześnie najniższym koszcie. Dążą również do użytkowania miejsc gwarantujących maksymalny zysk. Maksymalizacja przestrzennej efektywności działań wymaga podjęcia określonych decyzji lokalizacyjnych: 1) substytucji kosztów ziemi kosztami transportu (fizyczna dostępność), 2) substytucji kosztów produkcji kosztami transportu (wybór rynku), 3) substytucji utraconych korzyści aglomeracji kosztami transportu, i wreszcie 4) substytucji samowystarczalności handlem. Struktura przestrzenna wykształcona zgodnie z powyższymi regułami charakteryzuje się gradientami użytkowania ziemi oraz przestrzenną hierarchią miejsc (Morrill 1974).

\subsection{Przestrzenna analiza konkurencji jako wynik rozwoju teorii konkurencji monopolistycznej czy teorii konkurencji realnej}

W teorii konkurencji doskonałej analizy cenowe prowadzone są przy założeniu ceteris paribus. Zakłada się zatem, że jedyną determinantą popytu jest cena. E. Chamberlin (1933) proponuje natomiast uzależnienie popytu od lokalizacji. Analizy prowadzone powinny być zatem przy założeniu niezmienności wszystkich czynników z wyjątkiem położenia. Koncentracja przestrzenna działalności gospodarczej najczęściej występuje w dwóch przypadkach. Po pierwsze, w jednej przestrzeni lokalizowane będą przedsiębiorstwa oferujące produkty komplementarne. Po drugie, koncentracja dotyczyć będzie przedsiębiorstw oferujących produkty substytucyjne. Wspólna lokalizacja gwarantować ma konsumentom dostęp do większego rynku, zapewnić większy wybór, a w konsekwencji czynić bardziej zyskowną działalność wszystkich konkurujących ze sobą podmiotów (Chamberlin 1933). J.M. Clark (1955) zwraca natomiast uwagę na wybór lokalizacji unikalnej jako postępowanie przeciwne zjawisku koncentracji. Podkreśla, że procesy monopolistyczne są typowe dla zjawiska konkurencji. Ujawniają się choćby, gdy firma różnicuje siebie lub swoje produkty od oferty innych przedsiębiorstw. Jednym ze sposobów wspomnianego różnicowania jest właśnie wybór unikalnej lokalizacji.

E. Chamberlin (1933) rozróżnia dodatkowo pojęcie renty gruntowej wiejskiej i miejskiej. Wskazuje, że czynnik lokalizacji w całości determinuje rentę grunto- 
wą miejską, a tylko częściowo - wiejską. Renta gruntowa wiejska zależy odwrotnie proporcjonalnie od odległości od rynku zbytu. Renta miejska natomiast jest zależna od konkretnej lokalizacji. Za nieruchomość gruntową w mieście zapłacimy więcej wtedy, jeżeli mamy szansę w jej obrębie zrealizować większą sprzedaż. Renta miejska zależy zatem wprost proporcjonalnie od preferencji lokalizacyjnych konsumentów. Renta miejska jest zatem korzyścią z monopolizacji zasobu, jakim jest możliwość prowadzenia sprzedaży w konkretnym miejscu.

\subsection{Ekonomia ewolucyjna a geografia ekonomiczna: ewolucyjna geografia ekonomiczna}

R.A. Boschma i K. Frenken (2006) zwracają uwagę, że zwrot który nastąpił na początku lat 80. XX wieku w stronę instytucjonalizmu zaznaczył się znacznie silniej w geografii ekonomicznej niż w ekonomii. Badania nabrały charakteru interdyscyplinarnego, zaczęły wykorzystywać dorobek takich nauk, jak m.in. socjologia, kulturoznawstwo, politologia. Od początku lat 90 . XX wieku zaobserwowano natomiast znaczące zainteresowanie neoklasycznych ekonomistów zagadnieniami przestrzennymi (nowa geografia ekonomiczna). W tym samym czasie odnotowano spadek zainteresowania geografów kwestiami ekonomicznymi. R.A. Boschma i K. Frenken (2006) sugerują, że zbliżenie środowisk ekonomicznego i geograficznego mogłoby nastąpić poprzez przyjęcie za wyjściowych w dyskusji naukowej założeń ekonomii ewolucyjnej (ewolucyjna geografia ekonomiczna). P. Brouder (2014a) definiuje ewolucyjną geografię ekonomiczną jako dyscyplinę zajmującą się długoterminowymi procesami przekształceń gospodarki, uwarunkowanymi przestrzennie i historycznie. Przez analogię do ekonomii ewolucyjnej, geografia odrzuca założenie o statyczności i równowadze przestrzennych systemów gospodarczych. Przedmiotem zainteresowań ekonomii ewolucyjnej jest określone przez J.A. Schumpetera (2009) „twórcze burzenie” aktualnych struktur gospodarczych, zaś geografii - przestrzenne uwarunkowania tego procesu. Ewolucyjna geografia ekonomiczna ukształtowana została w opozycji do innych popularnych nurtów geograficznych: nowej geografii ekonomicznej będącej rozwinięciem teorii neoliberalnej oraz geografii instytucjonalnej, związanej ściśle z tożsamym nurtem ekonomicznym. Różnice między wskazanymi teoriami zaprezentowano w tab. 3.

C. Sanz-Ibáñez i S.A. Clavé (2014) charakteryzują trzy najważniejsze nurty ewolucyjnej geografii ekonomicznej. W nurcie darwinistycznym ewolucja przedsiębiorstw traktowana jest jako proces konkurencji, powiązany z ciągłym dążeniem do zróżnicowania (będącego źródłem przewagi konkurencyjnej) oraz eliminacji konkurentów. Teoria złożoności powstała dzięki implementacji do nauk społecznych wyników analizy nierównowagowych stanów termodynamicznych. Teoria ta bada ewoluujące firmy rozpatrując ich rozwój, samoorganizację i zachowania adaptacyjne. Analiza zależności od ścieżki zakłada, że rozwój 
przedsiębiorstw uwarunkowany jest ich wcześniejszą historią. Jednakże przywiązanie do ścieżki rozwojowej nie ma charakteru skrajnie deterministycznego, możliwe są modyfikacje istniejącej lub stworzenie całkiem nowej ścieżki rozwojowej.

Tabela 3

Nowa geografia ekonomiczna, instytucjonalizm a ewolucjonizm geograficzny

\begin{tabular}{|c|c|c|c|}
\hline $\begin{array}{c}\text { Zakres porównania } \\
\text { kierunków } \\
\text { badawczych }\end{array}$ & $\begin{array}{l}\text { Nowa geografia } \\
\text { ekonomiczna }\end{array}$ & $\begin{array}{l}\text { Instytucjonalizm } \\
\text { geograficzny }\end{array}$ & $\begin{array}{c}\text { Ewolucyjna } \\
\text { geografia } \\
\text { ekonomiczna }\end{array}$ \\
\hline Metodyka badań & $\begin{array}{c}\text { Modelowanie } \\
\text { ekonometryczne }\end{array}$ & Studia przypadków & $\begin{array}{c}\text { Modelowanie } \\
\text { ekonometryczne } \\
\text { i studia przypadków }\end{array}$ \\
\hline $\begin{array}{c}\text { Charakter } \\
\text { wnioskowania }\end{array}$ & Dedukcyjny & Indukcyjne & $\begin{array}{l}\text { Dedukcyjny } \\
\text { i indukcyjny }\end{array}$ \\
\hline Cel badań & $\begin{array}{l}\text { Zdiagnozowanie } \\
\text { zaburzeń występują- } \\
\text { cych w „,neutralnej } \\
\text { przestrzeni” }\end{array}$ & $\begin{array}{l}\text { Zrozumienie lokalnej } \\
\text { specyfiki „prawdzi- } \\
\text { wych miejsc” }\end{array}$ & $\begin{array}{l}\text { Wyjaśnienie prze- } \\
\text { strzennej zmienności } \\
\text { czynników umożli- } \\
\text { wiających podmio- } \\
\text { tom gospodarczym } \\
\text { eliminację konku- } \\
\text { rencji }\end{array}$ \\
\hline $\begin{array}{l}\text { Zakładany cel dzia- } \\
\text { łalności (lokalizacji) } \\
\text { badanych podmio- } \\
\text { tów gospodarczych }\end{array}$ & $\begin{array}{l}\text { Maksymalizacja } \\
\text { korzyści (lokalizacja } \\
\text { daje rentę ekono- } \\
\text { miczną) }\end{array}$ & $\begin{array}{l}\text { Postępowanie zgod- } \\
\text { nie z obowiązującymi } \\
\text { regułami (lokalizacja } \\
\text { daje zasady działania) }\end{array}$ & $\begin{array}{c}\text { Niekończące się } \\
\text { działania na rzecz } \\
\text { rozwoju (lokaliza- } \\
\text { cja daje dostęp do } \\
\text { wiedzy) }\end{array}$ \\
\hline $\begin{array}{l}\text { Efekt działalności } \\
\text { badanych podmio- } \\
\text { tów gospodarczych }\end{array}$ & Równowaga & Nierównowaga & Nierównowaga \\
\hline $\begin{array}{l}\text { Racjonalność działań } \\
\text { badanych podmio- } \\
\text { tów gospodarczych }\end{array}$ & Pełna & Ograniczona & Ograniczona \\
\hline $\begin{array}{c}\text { Determinanty dzia- } \\
\text { łalności badanych } \\
\text { podmiotów gospo- } \\
\text { darczych }\end{array}$ & $\begin{array}{l}\text { Ekonomiczne } \\
\text { (zależność } \\
\text { od kosztów) }\end{array}$ & $\begin{array}{c}\text { Społeczne } \\
\text { i instytucjonalne } \\
\text { (zależność } \\
\text { od miejsca) }\end{array}$ & $\begin{array}{l}\text { Zdolność do tworze- } \\
\text { nia innowacji } \\
\text { (zależność od przyję- } \\
\text { tej ścieżki rozwoju) }\end{array}$ \\
\hline $\begin{array}{c}\text { Zakres czasowy } \\
\text { analiz } \\
\end{array}$ & Statyczne & Statyczne & Dynamiczne \\
\hline $\begin{array}{l}\text { Zakres przestrzenny } \\
\text { analiz }\end{array}$ & $\begin{array}{l}\text { Wnioskowanie } \\
\text { o mikroskali } \\
\text { w oparciu o badania } \\
\text { makroskalowe }\end{array}$ & $\begin{array}{l}\text { Wnioskowanie } \\
\text { o makroskali } \\
\text { w oparciu o badania } \\
\text { mikroskalowe }\end{array}$ & $\begin{array}{c}\text { Wnioskowanie } \\
\text { o mezoskali } \\
\text { w oparciu o badania } \\
\text { makro- i mikro- } \\
\text {-skalowe }\end{array}$ \\
\hline
\end{tabular}

Źródło: opracowanie własne na podstawie: R.A. Boschma i K. Frenken (2006: 277-291) 
P. Maskell (2001) podkreśla, że na wielu poziomach przestrzennych możliwa i celowa jest dyskusja nad stosowanymi przez przedsiębiorstwa zasobami kluczowymi (determinującymi pozycję konkurencyjną), różnorodnością tych zasobów, jak również nad możliwością substytucji tych zasobów. Co więcej, sama przestrzeń może być uznana za zasób kluczowy. P. Maskell (2001) zwraca bowiem uwagę na przedsiębiorstwa, dla których jedynym czynnikiem pozwalającym wygrać walkę konkurencyjną jest lokalizacja w korzystnym miejscu. I to w oparciu o lokalizację budowana jest strategia tych firm. P. Maskell (2001) sugeruje również nowe spojrzenie na kwestię zróżnicowania położenia. Kiedyś różne lokalizacje dawały różny dostęp do zasobów naturalnych (mowa o zlokalizowanych zasobach naturalnych). Współcześnie, w różnych lokalizacjach w różnym stopniu rozwija się zdolność do tworzenia różnorodnych zasobów wykorzystywanych przez firmy (mowa o zlokalizowanych zasobach wytworzonych).

Warto podkreślić, że metodologia ewolucyjnej geografii ekonomicznej znakomicie sprawdza się w badaniach rozwoju regionalnego. Region może być bowiem traktowany jako relatywnie jednorodny (w stosunku do innych regionów) zbiór zasobów umożliwiających ewolucyjne osiągnięcie przewagi konkurencyjnej wobec innych jednostek przestrzennych (Brouder i Eriksson 2013). Dzięki rozwojowi ewolucyjnej geografii ekonomicznej możliwe stało się wyjaśnienie postępującego zróżnicowania obserwowanego wewnątrz regionu w sytuacji, gdy dąży on do osiągnięcia przewagi konkurencyjnej nad innymi regionami. Możliwa stała się również dyskusja nad dynamiką rozwoju regionalnego. W rezultacie wykorzystania dorobku ekonomii ewolucyjnej w geografii ekonomicznej rozpoczęto badania nad ewolucją różnorodności przestrzennej, stwarzającej szansę powstania innowacji w konkretnych lokalizacjach. R.A. Boschma i J.G. Lambooy (1999) wskazują, że w procesie rozwoju innowacji należy odrzucić koncepcje bazujące na polaryzacji rozwoju innowacji lub dyfuzji innowacji na rzecz koncepcji związanych z urbanizacją.

P. Maskell (2001) wskazuje na dwa ograniczenia możliwości wprowadzenia nowych teorii do geografii ekonomicznej. Pierwsze ma charakter uniwersalny i odnosi się do kwestii zgodności nowej teorii z podstawowymi założeniami samej dyscypliny, do której teoria ma być wprowadzona. Drugie ograniczenie dotyczy bezpośrednio geografii ekonomicznej. Wprowadzane do geografii ekonomicznej nowe teorie dotyczące aktywności gospodarczych człowieka powinny umożliwiać wnioskowanie na różnych poziomach agregacji przestrzennej, a więc zarówno w skali lokalnej, regionalnej, krajowej, jak i globalnej (Maskell 2001). Konieczność wielopoziomowej analizy procesów konkurencyjnych podkreślają sami ekonomiści. B. Czerniachowicz (2012) wskazuje na pięć poziomów konkurencji: 1) mikro-mikro - konkurencyjność odbywa się wewnątrz przedsiębiorstwa, np. między pracownikami, 2) mikro - mowa o konkurowaniu pojedynczych przedsiębiorstw, 3) mezo - wskazuje się na konkurujące ze sobą sektory, 4) makro - mowa o konkurencji pomiędzy krajami i 5) mega - konkurencyjność grup krajów w wymiarze globalnym. 


\subsection{Ekonomia ewolucyjna a geografia behawioralna}

Geografia behawioralna podkreśla, że wybór lokalizacji nie musi być optymalny. Co więcej, zdolność przedsiębiorstw do optymalizacji decyzji lokalizacyjnych jest niezwykle zróżnicowana, zależna zarówno od kompetencji pracowników podejmujących decyzje lokalizacyjne, jak i dostępnej informacji. Tym samym, w ocenie omawianych decyzji należało odejść od determinizmu na rzecz prawdopodobieństwa. Firmy dysponujące odpowiednim kapitałem ludzkim i pełniejszą wiedzą mają większą szansę (prawdopodobieństwo) podjąć lepszą decyzję lokalizacyjną (Boschma i Lambooy 1999).

Bliskość przestrzenna konkurujących ze sobą przedsiębiorstw jest katalizatorem innowacji, ponieważ stymuluje proces kolektywnego uczenia się. Bliskość przestrzenna rywalizujących firm sprzyja mobilności pracowników, którzy są przecież podstawowym nośnikiem wiedzy. Konkurujące firmy zakorzenione w jednym środowisku przestrzennym funkcjonują $w$ tych samych, często nieformalnych sieciach zrzeszających lokalnych aktorów. Co więcej, przedsiębiorstwa te działają w ramach jednej kultury przedsiębiorczości. Dochodzi do przestrzennej koncentracji wyspecjalizowanego kapitału ludzkiego oraz do powstania lokalnych instytucji wspierających konkretne dziedziny przedsiębiorczości. Wszystko to sprzyja wymianie wiedzy pomiędzy firmami. Można zatem przyjąć, że większe skupiska konkurujących przedsiębiorstw sprzyjają bardziej wymianie wiedzy i powstawaniu innowacji niż skupiska mniejsze. Warto również zauważyć, że ze względu na wspomniane zasoby kapitału ludzkiego i społecznego, większe skupiska konkurujących przedsiębiorstw przyciągają nowe firmy - zarówno spoza obszaru, jak powstające w wyniku oddzielenia się od firm już istniejących (Boschma i Lambooy 1999).

Zjawisku koncentracji geografia behawioralna przeciwstawia procesy dyfuzyjne. P. Haggett (1975) wyróżnia następujące rodzaje przestrzennej dyfuzji zjawisk: dyfuzję relokacyjną oraz dyfuzję ekspansywną, którą dzieli na dyfuzję zakaźną oraz dyfuzję kaskadową. Dyfuzja relokacyjna oznacza, że zjawisko podlegające procesowi pojawia się w nowych obszarach, ale ustępuje $\mathrm{z}$ obszarów pierwotnych. Dyfuzja ekspansywna natomiast oznacza zwiększenie obszaru objętego zjawiskiem. Jak wspomniano, dyfuzja ekspansywna może odbyć się w formie dyfuzji zakaźnej. Zjawisko rozprzestrzenia się poprzez bezpośredni kontakt jednostek, przenosi się z obszaru pierwotnego na terytoria bezpośrednio sąsiadujące. Dyfuzja ekspansywna może zostać również zrealizowana w sposób kaskadowy, inaczej hierarchiczny. Zjawisko przenosi się na obszary występujące wyżej lub niżej w strukturze, np. $z$ centrum na peryferia, $\mathrm{z}$ metropolii do miasta. Znakomitym przykładem dyfuzji kaskadowej jest dyfuzja innowacji. Różny charakter procesów dyfuzyjnych sprawia, że różnie można rozumieć pojęcie odległości między obszarami, między którymi dochodzi do dyfuzji zjawisk. Odległość i sąsiedztwo 
są bowiem kluczowymi zmiennymi opisującymi kierunki i tempo dyskutowanego procesu. Odległość między obszarami można określić korzystając z tradycyjnych miar geograficznych (dystans geograficzny, czas, koszt), ale również z liczby stopni dzielących obszary występujące w określonej strukturze hierarchicznej (Haggett 1975).

\subsection{Zastosowanie założeń teorii zasobowej do analizy koncentracji przestrzennej procesów konkurencji}

Analiza rozmieszczenia zasobów decydujących o przewadze konkurencyjnej przedsiębiorstw ma charakter obiektywny. Oznacza sprawdzenie występowania określonych zasobów w zadanych lokalizacjach. Z drugiej strony, analiza rozmieszczenia zasobów wykorzystywanych przez firmy w budowaniu przewagi konkurencyjnej musi uwzględniać zróżnicowanie podmiotowe (różne przedsiębiorstwa) i przestrzenne (różne lokalizacje) zdolności do wykorzystania omawianych zasobów i oceny ryzyka wykorzystania tych zasobów (Haggett 1975).

D.B. Audretsch i M.P. Feldman (1996) wskazują na kilka czynników koncentracji przestrzennej innowacji $\mathrm{w}$ poszczególnych działach gospodarki. Po pierwsze, przestrzenna koncentracja innowacji zależeć będzie od koncentracji danej działalności gospodarczej w ogóle. Po drugie, uzależniona będzie od przestrzennego rozkładu wydatków na działalność badawczo-rozwojową. Po trzecie, związana będzie z zapotrzebowaniem na wysokokwalifikowanych specjalistów w danym dziale gospodarczym. Wreszcie po czwarte, przestrzenna koncentracja innowacji determinowana będzie lokalizacją instytucji prowadzących działalność badawczo-rozwojową, np. uniwersytetów (Audretsch i Feldman 1996).

\subsection{Związki między postrzeganiem konkurencji w socjologii ekonomicznej i w geografii czlowieka}

Jak wskazuje A. Lisowski (2003), w geografii człowieka został zaakceptowany neobehawioryzm (behawioralizm) zakładający, że między bodźcami a reakcją pośredniczy świadomość człowieka, stany psychiczno-świadomościowe, zdolność do zmysłowo-umysłowego poznawania otaczającej rzeczywistości i wartościowania jej. Zrozumienie zachowań poprzez percepcję, postawy, preferencje, satysfakcję w nurcie behawioralnym zbliżyło geografię do człowieka, do psychologii. Odwołać się można choćby do próby określenia wpływu religii na postawy ekonomiczne człowieka (Weber 2015), przy czym badania te podejmowane były również przez geografów (Haggett 1975). Oczekiwano, że badania jednostek okażą się bardziej efektywne w identyfikacji natury relacji człowieka ze środowiskiem niż badania dużych zbiorowości społecznych. Zakładano też możliwość nadania interpretacji jednostkowych zachowań charakteru uniwersalnego zgodnie z założeniami emergentyzmu (Lisowski 2003). 
Współcześnie obserwujemy postępujące odhumanizowanie stosunków międzyludzkich i jednoczesne ich zwielokrotnienie wywołane rozwojem technologii informacyjno-komunikacyjnych. Coraz mniejsze znaczenie ma uczestnictwo w pojedynczych grupach społecznych. Zyskuje na znaczeniu umiejętność przystosowywania się do dynamicznie zmieniających się, coraz to nowych sytuacji społecznych. Tym samym rozszerza się przestrzeń abstrakcyjna (uniwersalna, idealna) kosztem przestrzeni konkretnej (doświadczanej przez jednostkę) (Lisowski 2003).

Idąc za A. Lisowskim (2003), struktury gospodarcze i struktury przestrzenne uznać należy za całkowicie spójne. Struktury te nie są bowiem różnymi relacjami, a wyłącznie różnymi aspektami tej samej relacji. Podmioty zakorzenione $\mathrm{w}$ przestrzeni globalnej, korzystając z przestrzeni lokalnych w swojej działalności, muszą uwzględnić lokalne warunki, a często dostosować się do nich. $\mathrm{Z}$ drugiej strony, podmioty zakorzenione w przestrzeni lokalnej, pragnąc nawiązać współpracę z podmiotami przestrzeni globalnej, muszą podnieść swoją atrakcyjność, konkurencyjność w wymiarze globalnym.

\section{Konsekwencje oddziaływań metodologicznych ekonomii i geografii ekonomicznej dla rozwoju geografii turyzmu i geografii hotelarstwa}

W niniejszej części opracowania przedstawiono konsekwencje wcześniej omówionych zmian w ekonomicznych i geograficznych teoriach konkurencji dla badań podejmowanych w zakresie analizy przestrzennych relacji między przedsiębiorstwami w sektorze turystycznym, a w szczególności w hotelarstwie. Warto jednocześnie zauważyć, że M. Ma i R. Hassink (2013) ledwie kilka lat temu wskazywali na dominację teorii geograficznych poświęconych zagadnieniom przestrzennym produkcji przemysłowej, sugerując jednocześnie niedostatek opracowań poświęconych usługom (w tym usługom turystycznym, a w szczególności hotelarskim), które w strukturze większości współczesnych systemów gospodarczych mają udział większy niż przemysł.

Dla zrozumienia konsekwencji przemian metodologicznych ekonomii i geografii ekonomicznej dla rozwoju geografii turyzmu, a w szczególności geografii hotelarstwa, kluczowym jest zdefiniowanie aktualnej problematyki badawczej wymienionych subdyscyplin geografii. P. Brouder i R.H. Eriksson (2013) wskazują na następujące problemy badawcze dotyczące geografii turyzmu, które proponują rozwiązywać z wykorzystaniem metodologii ewolucyjnej geografii ekonomicznej: 1) analiza rozwoju regionów turystycznych w oparciu o analizę zależności od ścieżki, z uwzględnieniem możliwości i uwarunkowań tworzenia nowych wzorców rozwojowych, 2) analiza rozgałęzień regionalnych, a więc powstawania $\mathrm{w}$ gospodarce regionalnej nowych rodzajów przedsiębiorstw na bazie już istniejących (np. przedsiębiorstwa typu spin-off), 3) analiza usieciowie- 
nia przedsiębiorstw sektora turystycznego i transferu wiedzy pomiędzy firmami turystycznymi oraz znaczenia tych procesów dla rozwoju regionalnego, 4) analiza postaw przedsiębiorczych w sektorze turystycznym oraz znaczenia tych postaw dla gospodarki regionalnej.

A. Kowalczyk (2001) wyróżnia następujące problemy badawcze geografii hotelarstwa: 1) lokalizacja obiektów noclegowych i jej czynniki, 2) rozmieszczenie popytu na usługi noclegowe i jego determinanty, 3) zachowania przestrzenne głównych interesariuszy sektora usług noclegowych (zarządzający pojedynczymi obiektami, zarządzający sieciami i systemami hotelowymi, inwestorzy), 4) zróżnicowanie przestrzenne cen nieruchomości wykorzystywanych na potrzeby usług noclegowych, 5) przestrzenne aspekty powiązań sektora usług noclegowych z innymi działami gospodarki. Nieco inaczej na zagadnienia badań podejmowanych na gruncie geografii hotelarstwa patrzy P. Niewiadomski (2013). Wyróżnia on następujące problemy badawcze: 1) wielopodmiotowa struktura aktorów sektora hotelarskiego (na jednym biegunie znajdują się liczne hotele niezrzeszone, a na drugim - globalne systemy hotelowe), 2) zakorzenienie sieci hotelowych w przestrzeni, w której zlokalizowane są hotele sieci (problem dotyka internacjonalizacji sieci hotelowych, które lokalizują swoje hotele w kraju macierzystym lub poza jego granicami), 3) wpływ inwestycji hotelowych na rozwój gospodarczy (dla geografii hotelarstwa szczególnie istotne będzie oddziaływanie hoteli na rozwój lokalny i regionalny), 4) efektywność modeli biznesowych (bezpośrednie inwestycje, franczyza, leasing, kontrakty menedżerskie, grupy markowe) rozwijanych przez sieci i systemy hotelowe z uwzględnieniem zróżnicowania przestrzennego dostępności do zasobów kapitałowych.

\subsection{Ewolucyjne podejście do analizy zmian rozmieszczenia przedsiębiorstw turystycznych}

Ważnym wkładem nurtu ewolucyjnego do rozwoju geografii hotelarstwa są badania nad zmianami rozmieszczenia hoteli. Na uwagę zasługują badania podjęte przez S. Bégina (2000), a dotyczące rozwoju przekształceń struktur lokalizacyjnych hoteli w chińskim Xiamen, które zaszły od końca lat 70 . do schyłku $\mathrm{XX}$ w. Autor analizował zmiany w rozmieszczeniu hoteli, które skonfrontował z reformami gospodarki Chin, ale również rozwojem samego miasta i przekształceniami jego funkcji turystycznej. Podobny charakter miały prace podjęte przez A. Matczaka i T. Napierałę (2014), którzy analizowali zmiany w lokalizacji hoteli w Budapeszcie w latach 1982-2013. Autorzy w swojej pracy wskazali na uwarunkowania historyczne lokalizacji obiektów hotelarskich. Kwestie lokalizacyjne zestawili również z analizą efektów transformacji ustrojowej końca XX wieku. Rozwojem miasta, zmianami jego funkcji turystycznej oraz wcześniejszymi wydarzeniami rozwoju hotelarstwa V. Dökmeci i N. Balta (1999) thuma- 
czyli ewolucję rozmieszczenia hoteli w Stambule. Co ciekawe, zarówno w przypadku Budapesztu, jak i Stambułu zaobserwowano podobną ścieżkę rozwojową: 1) początkową koncentrację hoteli w ścisłym centrum, 2) stopniowe nasycenie całej przestrzeni miejskiej obiektami hotelowymi i wreszcie 3) ponowną koncentrację inwestycji hotelarskich w obszarze centralnym.

P. Brouder (2014b) sugeruje, że najpopularniejszą koncepcją przeniesioną z ekonomii ewolucyjnej na grunt geograficzny jest koncepcja zależności od ścieżki ( $\mathrm{z}$ ang. path dependence). Celem badań nurtu jest sprawdzenie, w jakim stopniu rozwój gospodarki turystycznej uzależniony jest od dotychczasowego rozwoju przestrzeni regionalnej. W przypadku stwierdzenia negatywnej zależności, dzięki badaniom powinno być możliwe wskazanie sposobu odejścia od dotychczas realizowanej ścieżki rozwoju. Badania mają zatem niezwykle aplikacyjny charakter dla zarządzania rozwojem turystyki na poziomie regionalnym. Badania zrealizowane przez P. Broudera i R.H. Erikssona (2012) w północnej Szwecji są znakomitym przykładem wykorzystania analizy zależności od ścieżki w badaniach zjawisk turystycznych. Autorzy starali się zweryfikować, jak wcześniejsze doświadczenia zawodowe przedsiębiorców (sprzed założenia firmy) oraz lokalizacja ich działalności determinowały trwałość ich przedsiębiorstw. Autorzy potwierdzili, że większe prawdopodobieństwo powodzenia mają firmy zakładane przez osoby dysponujące branżowym doświadczeniem oraz społecznie zakorzenione w lokalizacji uruchamianej firmy.

C.G. Helmers i in. (2009) analizują wpływ formy własności na podejmowane decyzje lokalizacyjne w hotelarstwie. Jako zmienną opisującą charakter podejmowanych decyzji inwestycyjnych autorzy przyjęli wielkość hotelu mierzoną liczbą pokoi. Autorzy wykazali, że niezależnie od struktury istniejących hoteli, nowe inwestycje będące własnością systemów hotelowych to zazwyczaj inwestycje w relatywnie duże obiekty. Hotele niezależne i hotele franczyzowe to obiekty lokalizowane na podobnych zasadach. W przypadku, gdy w bezpośrednim sąsiedztwie potencjalnej lokalizacji takich obiektów nie było hoteli dużych, decydowano się wybudować obiekty relatywnie większe. Nasycenie obszaru hotelami o większej liczbie pokoi skutkowało natomiast tym, że nowe obiekty niezależne lub franczyzowe projektowano z relatywnie mniejszą liczbą pokoi. Zatem, zależność decyzji lokalizacyjnych dotyczących obiektów niezależnych i franczyzowych od istniejących przestrzennych struktur konkurencji była większa niż decyzji lokalizacyjnych dotyczących obiektów będących własnością sieci.

A. Papatheodorou (2004) zwraca uwagę, że ewolucja przedsiębiorstw turystycznych zachodzi równolegle ze zmianami przestrzeni turystycznej. Obszary koncentracji ruchu turystycznego stają się jednocześnie obszarami działalności dużych międzynarodowych przedsiębiorstw funkcjonujących często w ramach globalnych sieci, co przede wszystkim dotyczy hoteli. Co więcej, działalność pośredników znacząco zmienia relacje konkurencyjne w przestrzeni recepcyjnej. 
Redukowana jest liczba kupujących produkty turystyczne bezpośrednio od ich wytwórców (hotelarzy, restauratorów, gestorów atrakcji turystycznych itd.), warunki takie określić można jako oligopson. Współpraca pomiędzy przedsiębiorstwami działającymi w obszarze recepcji zaczyna być realizowana w zupełnie innych skalach przestrzennych, do skali globalnej włącznie.

J.M. Rogerson (2013) podkreśla, że badacze dotąd chętniej zajmowali się analizą lokalizacji hoteli na poziomie miejskim niż krajowym. Jednakże, ogólne prawidłowości dotyczące obiektów w skali krajowej są dość dobrze rozpoznane. Po pierwsze, w przypadku lokalizacji hoteli kluczowe znaczenie mają czynniki związane z rozwojem turystyki biznesowej. Są to czynniki o charakterze politycznym, instytucjonalnym, infrastrukturalnym, a także dotyczące tzw. kapitału ludzkiego. Wszystkie te determinanty są istotnie zróżnicowane przestrzennie. Stąd wynikają przestrzenne różnice w koncentracji hoteli. Skupiska diagnozowane są w metropoliach i dużych miastach oraz największych miejskich centrach obsługi masowej turystyki wypoczynkowej.

Dyskutując o nurtach rozwijanych w geografii, a odciskających swoje piętno na badaniach zjawisk turystycznych wspomnieć należy funkcjonalizm. Kierunek ten pozwala całościowo ująć funkcjonowanie badanego systemu (np. gospodarki turystycznej) na danym obszarze (Suliborski 2010). Badania funkcjonalne, spotykane dość często w geografii turyzmu, łączą tę subdyscyplinę geograficzną z dorobkiem ewolucyjnej geografii ekonomicznej oraz ekonomii ewolucyjnej. Funkcja turystyczna jest bowiem ważnym katalizatorem ewolucji przestrzeni turystycznej. Wnioskując na podstawie badań zrealizowanych przez K. Krzesiwo i M. Mikę (2011) twierdzić można, że w przypadku, gdy funkcja turystyczna jest znacząca dla gospodarki obszaru, wiąże się z masowymi formami turystyki, wówczas może stać się podstawowym czynnikiem rozwoju na poziomie lokalnym czy regionalnym. K. Krzesiwo i M. Mika (2011) dowodzą jednocześnie, że zagadnienia konkurencji obszarów turystycznych, a przede wszystkim konkurencji przedsiębiorstw turystycznych były podejmowane niezwykle rzadko w geografii turyzmu i geografii hotelarstwa. Dowodzą jednak znaczenia takich studiów. Podkreślają, że zrozumienie przestrzennych aspektów procesów ewolucyjnych zachodzących w sektorze turystycznym, szczególnie odnoszących się do kwestii innowacji, jest kluczowe dla efektywnego zarządzania przestrzenią turystyczną czy przedsiębiorstwem turystycznym. Postulowana jest konieczność rozwoju ujęcia funkcjonalnego w badaniach nad przedsiębiorstwami hotelowymi. J.M. Rogerson (2012) wskazuje, że hotele to istotny czynnik determinujący morfologię, wizerunek, a przede wszystkim funkcje miasta. $Z$ jednej strony, przemiany tego ważnego składnika zagospodarowania turystycznego w szczególności oddziaływać będą na ewolucję przestrzeni miejskiej. Z drugiej strony natomiast, nie tylko hotele same $\mathrm{z}$ siebie, ale również przestrzenne relacje konkurencyjne między hotelami będą oddziaływać na wymienione elementy miasta: morfologię, wizerunek i funkcje. 


\subsection{Ujęcie ewolucyjne w geograficznych studiach nad innowacyjnością przedsiębiorstw turystycznych}

P. Brouder i R.H. Eriksson (2013) podkreślają, że ewolucyjna geografia ekonomiczna najlepiej thumaczy przestrzenne uwarunkowania i efekty zmian zachodzących w innowacyjnych przemysłach wysokich technologii. Brakuje natomiast wystarczającego potwierdzenia skuteczności teorii dla sektorów mało innowacyjnych, a za taki autorzy uważają przemysł turystyczny. Tym samym, znaczenie sektora turystycznego dla transferu wiedzy do regionu, a w konsekwencji rozwoju regionalnego jest inne niż przemysłów wysokich technologii. P. Brouder (2014a) proponuje, aby sprawdzeniu powyższej tezy poświęcić badania ewolucyjnej geografii ekonomicznej nad przemysłem turystycznym. Dzięki takim badaniom określić można efektywność różnorodnych strategii rozwoju regionalnego, w ramach których przedsiębiorstwa turystyczne odgrywać mogą zróżnicowaną rolę.

Najpopularniejszym przykładem implementacji metody analizy zależności od ścieżki w badaniu rozwoju turystyki jest model cyklu życia przestrzeni turystycznej (z ang. Tourism Area Life Cycle, dalej TALC) (Butler 1980, 2006). Model wykorzystywany był m.in. przez G. Gołembskiego i in. (2010) w badaniach inwestycji turystycznych realizowanych w województwie lubuskim. M. Ma i R. Hassink (2013) wskazują, że pierwowzorem omawianego modelu była koncepcja cyklu życia produktu turystycznego. Podkreślają, że utożsamianie złożonej przestrzeni geograficznej z pojedynczym produktem jest zbyt daleko idącym uproszczeniem. Co więcej, w ewolucyjnej geografii ekonomicznej wskazuje się, że znaczenie terminu „ewolucja” jest znacznie obszerniejsze, również ze względu na zakres czasowy, niż rozumienie terminu „cykl życia”. Wydaje się zatem, że do analizy rozwoju obszaru turystycznego należy poszukiwać bardziej zaawansowanych metod niż model TALC, przy czym metody te dostępne są również w dorobku ewolucyjnej geografii ekonomicznej, np. w zakresie koewolucji, a więc jednocześnie i współzależnie zachodzącej ewolucji różnych dziedzin gospodarki turystycznej, jak również instytucji rządowych i pozarządowych odpowiedzialnych za rozwój turystyki. A. Papatheodorou (2004) proponuje uzupełnienie modelu TALC o założenie dotyczące dwoistej natury przekształceń popytu i podaży turystycznej: egzo- i endogeonicznej. Zmiany egzogeniczne są niezależne od podmiotów odpowiedzialnych za rozwój turystyki w obszarze recepcji. Mowa przykładowo o zmianach mody i gustów konsumentów, zmianach technologii transportu pasażerskiego czy katastrofach naturalnych. Zmiany endogeniczne, inaczej strukturalne, związane są z działaniami podejmowanymi przez interesariuszy rozwoju turystyki w obszarze recepcji.

C. Sanz-Ibáñez i S.A. Clavé (2014) definiują katalizatory przemian obszarów recepcji turystycznej. Wskazują, że przemiany kierunków turystycznych możliwe są dzięki działaniom podejmowanym przez interesariuszy rozwoju turystyki, przy 
czym największe znaczenie mają działania podejmowane kolektywnie, bazujące na możliwie szerokich zasobach dostępnej wiedzy. Ewolucja przestrzeni recepcji turystycznej jest uwarunkowana historycznie, jest obarczona decyzjami podjętymi w przeszłości. Ewolucja ma charakter kontekstualny, zależy bowiem od społecznych, ekonomicznych, środowiskowych i politycznych struktur i zjawisk na poziomie zarówno lokalnym, dotyczącym bezpośrednio analizowanej przestrzeni recepcji, jak i w skali globalnej. P. Brouder i R.H. Eriksson (2013) wskazują, że katalizatorem ewolucji przestrzeni turystycznej jest heterogeniczny charakter przemysłu turystycznego. Sprawne funkcjonowanie sektora turystycznego w regionie wymaga dostępności zróżnicowanych zasobów, przede wszystkim różnorodnej wiedzy, a tę łatwiej wytworzyć w zróżnicowanych przedsiębiorstwach. Różnorodność zasobów jest zatem immanentną cechą turystyki, ułatwia zbudowanie unikalnej kombinacji omawianych zasobów na poziomie regionalnym. W konsekwencji, osiągnięcie pozycji konkurencyjnej przez region zorientowany na rozwój turystyki jest relatywnie prostsze.

\subsection{Teoria organizacji a strategie lokalizacyjne hoteli}

Istotna część badań podejmowanych w geografii hotelarstwa powstała na gruncie dorobku modernistycznej teorii organizacji, będącej ekonomiczną postacią ogólnej teorii systemów, a ściślej jej ekologicznego nurtu. Jednostka (np. człowiek, konsument, przedsiębiorstwo) traktowana jest jako część wielopodmiotowej struktury o zmiennej konfiguracji (ekosystemu), pozostająca z nią w dynamicznych, skomplikowanych relacjach. Opisanie takich skomplikowanych relacji wymaga tworzenia modeli pokazujących rzeczywistość w sposób uproszczony, możliwy do zrozumienia, ale jednocześnie kompleksowy (Koźmiński i Latusek-Jurczak 2011).

Inwestycje międzynarodowych sieci hotelarskich można rozpatrywać w kontekście teorii J.H. Dunninga (2001), gdzie oceniany jest wpływ następujących czynników (stąd nazwa teorii: paradygmat OLI, z ang. Ownership, Location, Internalization) na skłonność do inwestowania poza granicami kraju: 1) własność - inwestor dysponuje określonymi zasobami, dzięki którym nowy hotel może osiągnąć przewagę konkurencyjną, 2) lokalizacja - nie wszystkie wykorzystywane zasoby mają charakter mobilny, stąd przy inwestycjach zagranicznych niezbędny jest dostęp do kluczowych zasobów w lokalizacji nowego hotelu) i 3) internacjonalizacja - skłonność inwestora do wykorzystywania swoich zasobów na skalę międzynarodową. Jak wskazują C. Johnson i M. Vanetti (2005) ostatni z wymienionych czynników decydować będzie o tym, czy inwestor zdecyduje się na inwestycje poza swoim krajem. Dwa pierwsze czynniki warunkować będą natomiast wybór konkretnej lokalizacji pod inwestycje zagraniczne. 


\subsection{Lokalizacja jako kluczowy zasób budowania przewagi konkurencyjnej przedsiębiorstw turystycznych}

J.A.C. Baum i S.J. Mezias (1992) definiują konkurencję jako funkcję poszukiwania zasobów wykorzystywanych przez przedsiębiorstwa. Intensywność konkurencji zależy od stopnia podobieństwa zasobów wykorzystywanych w działalności firmy. Autorzy za kluczowy zasób wykorzystywany przez hotele uznają lokalizację. Zatem, im bliżej siebie zlokalizowane będą hotele, tym bardziej będą ze sobą konkurować. Bliskość geograficzna jest zatem miernikiem poziomu konkurencji w usługach hotelarskich. W odniesieniu do omawianego zjawiska J.A.C. Baum i S.J. Mezias (1992) proponują stosować termin „zlokalizowanej konkurencji” (z ang. localized competition). B. Włodarczyk (2015) wyróżnia następujące modele lokalizacji hoteli w miastach: 1) lokalizacja ekonomiczna, ze względu na potencjalną rentę położenia hotelu, 2) lokalizacja z uwzględnieniem planów zagospodarowania przestrzennego, 3) lokalizacja mieszana, choć można ją nazwać również lokalizacją popytową, ze względu na opinie potencjalnych gości hotelu $\mathrm{z}$ jednej strony wpływające na osiąganą rentę, a $\mathrm{z}$ drugiej strony uwzględniające oczekiwania dotyczące ładu przestrzennego miejsca, w którym ma funkcjonować hotel.

Efekty aglomeracji firm usługowych są rezultatem zupełnie innych czynników niż w przypadku przedsiębiorstw produkcyjnych. W firmach usługowych, w tym hotelach, kluczowym czynnikiem sprzyjającym koncentracji przestrzennej jest obniżenie kosztów poszukiwania przez konsumenta informacji o ofercie, co bezpośrednio stymuluje popyt (Urtasun i Gutiérrez 2006). J.A.C. Baum i S.J. Mezias (1992) dowodzą, że korzyści wynikające z funkcjonowania w atrakcyjnej lokalizacji przewyższają minusy działania pod silną presją konkurencji. Równie uprawnionym jest jednak twierdzenie, że funkcjonowanie w bliskim sąsiedztwie zróżnicowanych, licznych obiektów konkurencyjnych mogło mieć charakter bezpośrednio stymulujący sukces podjętej działalności. R. Komppula (2014) zwraca uwagę na fakt, że konkurujące w danej lokalizacji przedsiębiorstwa łącznie decydować będą o konkurencyjności całego obszaru. Wśród działań pojedynczych przedsiębiorstw na rzecz budowania konkurencyjności obszaru recepcji turystycznej wymienić należy: 1) przygotowanie oferty spójnej z koncepcją oferty obszaru, 2) otwartość na współpracę z innymi przedsiębiorstwami i wreszcie 3) zainteresowanie inwestycjami sektorowymi w obszarze recepcji turystycznej.

A. Kalnins i W. Chung (2004) potwierdzili w swoich badaniach, że przedsiębiorstwa działające $w$ sektorach mało innowacyjnych, a do takich zaliczają większą część usług noclegowych (z wyłączeniem luksusowych obiektów sieciowych), powinny być lokalizowane możliwie blisko innych przedsiębiorstw tego typu. Bliskość lokalizacji oznacza, że nowo powstające obiekty noclegowe mogą 
korzystać z zasobów dostępnych w danej lokalizacji, a wykorzystywanych przez istniejące firmy. Mówią o efekcie „rozlewania się” (z ang. spillovers) zasobów. Autorzy podkreślają, że założenie będzie prawdziwe wyłącznie dla firm z działów gospodarczych o niskiej innowacyjności. Zasoby konkurencyjne przedsiębiorstw działających w kreatywnych sektorach wysokich technologii mają zazwyczaj niematerialny charakter, nie są mobilne. Wymiana takich zasobów między firmami odbywać będzie się na zupełnie innych zasadach (np. spin off).

W teorii zasobowej uznaje się, że konkurencja nie ma wyłącznie wymiaru cenowego, ale realizowana jest również na poziomie produktu, a więc zdolności do jego udoskonalania, zdolności do wprowadzania innowacji (Penrose 2011). Potwierdzają to wyniki badań T. Napierały (2013), który na podstawie analizy działalności hoteli w Polsce dowiódł, że cena nie musi być jedynym narzędziem budowania relacji konkurencyjnych $\mathrm{w}$ sektorze. W niektórych przypadkach w ogóle nie jest wykorzystywana jako takie narzędzie. Autor wykazał jednocześnie, że rynek (rozumiany jako ogół relacji podaży i popytu) nie musi być efektywnym źródłem wzorców dla podejmowanych przez hotele decyzji cenowych.

\section{Podsumowanie}

Niniejsze opracowanie z pewnością nie wyczerpuje studiów literaturowych, jakie należy przeprowadzić celem uzgodnienia wspólnego, wzajemnie inspirującego się dorobku teoretycznego ekonomii i geografii ekonomicznej, a dotyczącego procesów konkurencyjnych w sektorze usług hotelarskich. W artykule wskazano jednak sposób poszukiwania relacji metodologicznych pomiędzy różnymi dyscyplinami. Pokazano z jednej strony, że przemiany ekonomicznej teorii konkurencji odcisnęły piętno na rozwoju geografii ekonomicznej. Mowa przede wszystkim o nowej geografii ekonomicznej czy ewolucyjnej geografii ekonomicznej. Z drugiej natomiast strony udowodniono, że zrozumienie wcześniejszych wyników badań geograficznych na gruncie ekonomicznym, szczególnie odnoszących się do optymalizacji decyzji lokalizacyjnych, możliwe było dopiero po odrzuceniu założeń dotychczas obowiązujących teorii, a przeczących obserwowanej rzeczywistości. Dowiedziono jednocześnie znaczenia badań interdyscyplinarnych: podejmowanych na pograniczu ekonomii i geografii ekonomicznej. W oparciu o ciągle istniejącą lukę badawczą między poszczególnymi nurtami ekonomicznymi a geograficznymi poszukiwać należy szans rozwoju obu dyscyplin w zakresie studiów nad przestrzennymi kontekstami konkurencji przedsiębiorstw świadczących usługi hotelowe, czemu autor zamierza poświęcić kolejne swoje prace. 


\section{LITERATURA}

Audretsch D.B. i Feldman M.P., 1996, $R \&$ D Spillovers and the Geography of Innovation and Production, ,The American Economic Review”, 86(3), s. 630-640.

Barney J., 1991, Firm Resources and Sustained Competitive Advantage, „Journal of Management", $17(1)$, s. 99-120.

Bartkowiak P., 2014, Koncepcja wspótkreowania wartości dla klienta na przykładzie modelu DART, „Studia i Prace Kolegium Zarządzania i Finansów”, 136, SGH, s. 9-18.

Baum J.A.C., Mezias S.J., 1992, Localized Competition and Organizational Failure in the Manhattan Hotel Industry, 1898-1990, „Administrative Science Quarterly”, 37 (4), s. 580-604.

Bégin S., 2000, The Geography of a Tourist Business: Hotel Distribution and Urban Development in Xiamen, China, „Tourism Geographies”, 2 (4), s. 448-471.

Boschma R.A., Frenken K., 2006, Why is Economic Geography not an Evolutionary Science? Towards an Evolutionary Economic Geography, „Journal of Economic Geography," 6(3), s. 273-302.

Boschma R.A., Lambooy J.G., 1999, Evolutionary Economics and Economic Geography, „Journal of Evolutionary Economics”, 9(4), s. 411-429.

Brouder P., 2014a, Evolutionary Economic Geography: A New Path for Tourism Studies?, „Tourism Geographies”, 16(1), s. 2-7.

Brouder P., 2014b, Evolutionary Economic Geography and Tourism Studies: Extant Studies and Future Research Directions, ,Tourism Geographies”, 16(4), s. 540-545.

Brouder P., Eriksson R.H., 2012, Staying Power: What Influences Micro-firm Survival in Tourism?, „Tourism Geographies”, 15(1), s. 125-144.

Brouder P., Eriksson R.H., 2013, Tourism Evolution: On the Synergies of Tourism Studies and Evolutionary Economic Geography, „Annals of Tourism Research”, 43, s. 370-389.

Butler R.W., 1980, The Concept of a Tourist Area Cycle of Evolution: Implication for Management of Resources, „Canadian Geographer,” 24, s. 5-12.

Butler R.W., 2006, The Concept of a Tourist Area Cycle of Evolution: Implications for Management of Resources, [w:] Butler R.W. (red.), The Tourism Area Life Cycle: Applications and Modifications, Channel View Publications, Clevedon-Buffalo-Toronto, s. 3-12.

Chamberlin E., 1933, The Theory of Monopolistic Competition, Harvard University Press, Cambridge.

Clark J.M., 1955, Competition: Static Models and Dynamic Aspects, „The American Economic Review", 45(2), s. 450-462.

Conner K.R., 1991, A Historical Comparison of Resource-Based Theory and Five Schools of Thought within Industrial Organization Economics: Do We Have a New Theory of the Firm?, „Journal of Management”, 17 (1), s. 121-154.

Czerniachowicz B., 2012, Budowanie konkurencyjności przedsiębiorstwa $w$ podejściu zasobowym na podstawie firmy ,, a”, Studia i Prace Wydziału Nauk Ekonomicznych i Zarządzania Uniwersytetu Szczecińskiego, 25, s. 287-302.

Dierickx I., Cool K., 1989, Asset Stock Accumulation and Sustainability of Competitive Advantage, „Management Science”, 35, s. 1504-1511. 
Dökmeci V., Balta N., 1999, The Evolution and Distribution of Hotels in Istanbul, „European Planning Studies”, 7 (1), s. 99-109.

Dunning J.H., 2001, The Eclectic (OLI) Paradigm of International Production: Past, Present and Future, ,International Journal of the Economics of Business”, 8(2), s. 173-190.

Glapiński A., 2013, Kwestie metodologiczne podejścia ewolucyjnego $w$ ekonomii, „Gospodarka Narodowa”, 261-262(5-6), s. 5-17.

Gołembski G. i in., 2010, Investment decisions in the early stages of the tourism area life cycle, „Tourism: An International Interdisciplinary Journal”, 58(4), s. 361-377.

Granovetter M., 1985, Economic Action and Social Structure: The Problem of Embeddedness, „American Journal of Sociology”, 91 (3), s. 481-510.

Haggett P., 1975, Geography: A Modern Synthesis, Harper International Edition, New York-Evanston-San Francisco-London.

Hamel G., Doz Y.L., Prahalad C.K., 1989, Collaborate with Your Competitors - and Win, Harvard Business Review, Jan-Feb, s. 133-139.

Helmers C.G. i in., 2009, Entry Size, Ownership Form, and Spatial Location: An Analysis of the Hotel Industry, [w:] Agricultural \& Applied Economics Associations 2009 Joint Annual Meeting, Milwaukee, s. 1-20.

Howells J., Bessant J., 2012, Introduction: Innovation and Economic Geography: A Review and Analysis, ,Journal of Economic Geography”, 12 (5), s. 929-942.

Hunt S.D., 2000, A General Theory of Competition: Resources, Competences, Productivity, Economic Growth, Sage Publications Inc., Thousand Oaks-London-New Delhi.

Hunt S.D., 2011, The Theory of Monopolistic Competition, Marketing's Intellectual History, and the Product Differentiation Versus Market Segmentation Controversy, „Journal of Macromarketing”, 31 (1), s. 73-84.

Johnson C., Vanetti M., 2005, Locational Strategies of International Hotel Chains, „Annals of Tourism Research", 32 (4), s. 1077-1099.

Kalnins A., Chung W., 2004, Resource-Seeking Agglomeration: A Study of Market Entry in the Lodging Industry, „Strategic Management Journal”, 25 (7), s. 689-699.

Kirzner I., 2010, Konkurencja i przedsiębiorczość, Fijorr Publishing Company, Warszawa.

Komppula R., 2014, The Role of Individual Entrepreneurs in the Development of Competitiveness for a Rural Tourism Destination-A Case Study, „,Tourism Management”, 40, s. 361-371.

Kowalczyk A., 2001, Geografia hotelarstwa, Wydawnictwo Uniwersytetu Łódzkiego, Łódź.

Koźmiński A.K., Latusek-Jurczak D., 2011, Rozwój teorii organizacji, Wolters Kluwer Polska, Warszawa.

Krugman P., 1997, Development, Geography and Economic Theory, The MIT Press, Cambridge.

Krzesiwo K., Mika M., 2011, Ocena atrakcyjności turystycznej stacji narciarskich w świetle zagadnienia ich konkurencyjności-studium porównawcze Szczyrku i Białki Tatrzańskiej, „Prace Geograficzne”, 125, s. 95-110.

Lisowski A., 2003, Koncepcje przestrzeni w geografii człowieka, Wydział Geografii i Studiów Regionalnych Uniwersytetu Warszawskiego, Warszawa.

Lösch A., 1961, Gospodarka przestrzenna: Teoria lokalizacji, Państwowe Wydawnictwo Ekonomiczne, Warszawa. 
Ma M., Hassink R., 2013, An Evolutionary Perspective on Tourism Area Development, „Annals of Tourism Research”, 41, s. 89-109.

Markiewicz E., Niezgoda A., 2015, Zmiany w zachowaniach konsumentów na ryn$k u$ turystycznym $w$ erze społeczeństwa twórczego, Zeszyty Naukowe Uniwersytetu Szczecińskiego. Problemy Zarządzania, Finansów i Marketingu, 38, s. 37-45.

Maskell P., 2001, The Concept of the Firm in Economic Geography, „Economic Geography”, 77 (4), s. 329-344.

Matczak A., Napierała T., 2014, Zmiany w lokalizacji hoteli w Budapeszcie, [w:] Gołembski G., NiezgodaA. (red.), Turystyka wobec zmian współczesnego świata, Wydawnictwo Uniwersytetu Ekonomicznego w Poznaniu, Poznań, s. 127-139.

McCarthy J.E., 1968, Basic Marketing: A Managerial Approach, R.D. Irwin, Homewood. Mises L. von, 2007, Ludzkie działanie. Traktat o ekonomii, Fundacja Instytut Edukacji Ekonomicznej im. Ludwiga von Misesa, Wrocław.

Morrill R.L., 1974, The Spatial Organization of Society, Duxbury Press, Pacific Grove.

Napierała T., 2013, Przestrzenne zróżnicowanie cen uslug hotelowych w Polsce, Wydawnictwo Uniwersytetu Łódzkiego, Łódź.

Niewiadomski P., 2013, Towards an Economic-Geographical Approach to the Globalisation of the Hotel Industry, „Tourism Geographies: An International Journal of Tourism Space, Place and Environment", 16(1), s. 48-67.

Niezgoda A., 2013, Prosument na rynku turystycznym - próba zdefiniowania, Prace Naukowe Uniwersytetu Ekonomicznego we Wrocławiu, 304, s. 203-210.

Papatheodorou A., 2004, Exploring the Evolution of Tourism Resorts, „Annals of Tourism Research", 31(1), s. 219-237.

Penrose E., 2011, The Theory of the Growth of the Firm, Oxford University Press, Oxford.

Porter M.E., 2006, Strategia konkurencji: Metody analizy sektorów i konkurentów, Wydawnictwo MT Biznes, Warszawa.

Porter M.E., Millar V.E., 2001, W jaki sposób informacja wpływa na przewage konkurencyjna??, [Porter M.E. (red.)], Polskie Wydawnictwo Ekonomiczne, Warszawa.

Prahalad C.K., Hamel G., 1990, The Core Competence of the Corporation, Harvard Business Review, May-Jun, s. 79-90.

Rogerson J.M., 2012, The Changing Location of Hotels in South Africa's Coastal Cities, 1990-2010, „Urban Forum”, 23 (1), s. 73-91.

Rogerson J.M., 2013, The Economic Geography of South Africa's Hotel Industry 1990 -2010, „Urban Forum”, 24(3), s. 425-446.

Rumelt R.P., 1997, Towards a Strategic Theory of the Firm, [w:] Foss N.J. (red.), Resources, Firms, and Strategies: A Reader in the Resource-based Perspective, Oxford University Press, Oxford, s. 131-145.

Sanz-Ibáñez C., Clavé S.A., 2014, The Evolution of Destinations: Towards an Evolutionary and Relational Economic Geography Approach, „Tourism Geographies”, 16(4), s. 563-579.

Schumpeter J.A., 2009, Kapitalizm, socjalizm, demokracja, Wydawnictwo Naukowe PWN, Warszawa.

Suliborski A., 2010, Funkcjonalizm w polskiej geografii miast: Studia nad geneza i pojęciem funkcji, Wydawnictwo Uniwersytetu Łódzkiego, Łódź. 
Swedberg R., 2003, Principles of Economic Sociology, Princeton University Press, Princeton.

Szutowski D., 2016, Innovation and Market Value: The Case of Tourism Enterprises, Difin, Warsaw.

Toffler A., 1997, Trzecia fala, Państwowy Instytut Wydawniczy, Warszawa.

Urtasun A., Gutiérrez I., 2006, Hotel Location in Tourism Cities: Madrid 1936-1998, „Annals of Tourism Research”, 33 (2), s. 382-402.

Uzzi B., 1996, The Sources and Consequences of Embeddedness for the Economic Performance of Organizations: The Network Effect, „American Sociological Review”, $61(4)$, s. 674-698.

Vargo S.L., Lusch R.F., 2004, Evolving to a New Dominant Logic for Marketing, ,Journal of Marketing", 68(1), s. 1-17.

Weber M., 2015, Etyka protestancka $i$ duch kapitalizmu, Wydawnictwo Uniwersytetu Warszawskiego, Warszawa.

Włodarczyk B., 2015, Hotele w przestrzeni miejskiej Łodzi, „Turyzm”, 25 (2), s. 63-75.

\section{SPATIAL CONTEXTS OF THE COMPETITION IN THE HOTEL INDUSTRY}

Abstract Critique of neoclassical (neoliberal) understanding of the phenomenon of competition enabled in the XX century arising numerous new economic theories which defined and interpreted the phenomenon of competition in a brand new manner. Rejecting of assumptions of neoliberal theory (particularly assumptions on the market equilibrium, and on access to the market information) had significant impact on redefining methodology of economic geography research on spatial contexts of the competition. Finally, changes observed in economic geography influenced back on development of economics. The main goal of this paper is to describe simultaneous and reciprocal methodological impacts between economics and economic geography. However, the author deliberately focused on economic and geographical studies on spatial contexts of the competition in the hotel industry.

Keywords Competition, economics, economic geography, tourism geography, geography of hospitality.

Dr Tomasz Napierała

Zakład Geografii Hotelarstwa Instytut Geografii Miast i Turyzmu

Wydział Nauk Geograficznych

Uniwersytet Łódzki

e-mail: tomasz.napierala@poczta.fm 